WIDER Working Paper 2020/74

COVID-19: macroeconomic dimensions in the developing world

Tony Addison, ${ }^{1}$ Kunal Sen, ${ }^{2}$ and Finn Tarp ${ }^{1}$

June 2020

United Nations University World Institute for Development Economics Research 
Abstract: The COVID-19 pandemic represents an unprecedented global crisis. The task for economic policy is to help keep people alive, enterprises afloat, and households out of poverty. The pandemic has macroeconomic dimensions. First, it affects macroeconomic stability and growth. Second, the tools of macroeconomic policy-fiscal and monetary policy together with debt management and exchange rate policy — must deal with the economic shock. Simultaneously, policy makers must find fiscal space to fund health, social protection, and livelihood support. Third, success in dealing with the virus itself will be a big determinant of macroeconomic outcomes: the size of the GDP loss, the duration of the recession, and the outcomes for the fiscal deficit and debt ratios. This paper discusses these macroeconomic dimensions, focusing on the developing world. The paper concludes that the pandemic could reinforce the existing trend towards higher social inequality.

Key words: commodities, COVID-19, debt, growth, inequality, macroeconomic policy, poverty

JEL classification: E71, F01, I15, O11

Acknowledgements: Thank you to Lorraine Telfer-Taivainen for fast, efficient, and accurate editing.

${ }^{1}$ UNU-WIDER, Helsinki and Department of Economics, University of Copenhagen; ${ }^{2}$ UNU-WIDER, Helsinki and Global Development Institute, University of Manchester. Corresponding author: addison@wider.unu.edu.

This study has been prepared within the UNU-WIDER project on Academic Excellence.

Copyright (C) UNU-WIDER 2020

Information and requests: publications@wider.unu.edu

ISSN 1798-7237 ISBN 978-92-9256-831-3

https://doi.org/10.35188/UNU-WIDER/2020/831-3

Typescript prepared by Lorraine Telfer-Taivainen

United Nations University World Institute for Development Economics Research provides economic analysis and policy advice with the aim of promoting sustainable and equitable development. The Institute began operations in 1985 in Helsinki, Finland, as the first research and training centre of the United Nations University. Today it is a unique blend of think tank, research institute, and UN agency — providing a range of services from policy advice to governments as well as freely available original research.

The Institute is funded through income from an endowment fund with additional contributions to its work programme from Finland, Sweden, and the United Kingdom as well as earmarked contributions for specific projects from a variety of donors.

Katajanokanlaituri 6 B, 00160 Helsinki, Finland

The views expressed in this paper are those of the author(s), and do not necessarily reflect the views of the Institute or the United Nations University, nor the programme/project donors. 
The COVID-19 pandemic represents an unprecedented global crisis. Analysts make comparisons with the Great Depression of the 1930s. Time will tell. Meanwhile, the policy responses now underway will offset some of the pandemic's impact, but the recession is certain to be deeper than the global financial crisis (GFC) of 2008-09. The pandemic arrived suddenly, with little warning, and much of the final economic impact will depend on SARS-CoV-2 itself_-about which much is unknown - and the success or failure of efforts to contain and suppress it, and to develop and deploy a vaccine. This makes the economic outcomes highly uncertain, both in depth and duration.

The task for economic policy is to help keep people alive, enterprises afloat, people in jobs, and households out of poverty. That said complete success in each of these tasks is not possibleeven in the advanced economies with their considerable physical, human, institutional, and financial resources. The low-income countries (LICs) have many fewer resources, and food insecurity, and the existing diseases of poverty amplify the health impact of the pandemic. The middle-income countries (MICs) are vulnerable too, for many remain undiversified economies, over-dependent on commodity exports, and now hit by the global economic recession. That said, policy matters as does the quality of leadership in determining outcomes.

Many countries did not use the growth years to tackle social inequality and there is insufficient social protection across the developing world. This is a bad starting point in a pandemic when economic and social support needs to expand quickly. There is an awful tension between the need to suppress the virus and the desperate need of people to maintain their livelihood, limiting their ability to comply with social distancing. Serious social and economic damage therefore seems inescapable: the task is then to minimize the size of the impact on lives and living standards, and secure an inclusive recovery-one that does not leave the poor and vulnerable behind.

The pandemic has macroeconomic dimensions, both in its impacts as well as in policy responses. First, it affects macroeconomic stability and growth. Second, the tools of macroeconomic policy must deal with the economic shock (where the tools are fiscal and monetary policy together with debt management and exchange rate policy). Simultaneously, policy makers must find the fiscal space to fund health, social protection and livelihood support. Third, success in dealing with the virus will be fundamental to the pandemic's macroeconomic consequences - the size of the gross domestic product (GDP) loss, the duration of the recession, and the outcomes for the fiscal deficit and debt ratios. Policy must try to find enough fiscal space for the necessary public spending. Yet, LICs have extremely limited fiscal space, and will need more official development assistance (ODA) and other concessional financial assistance.

This paper discusses these macroeconomic dimensions, focusing on the developing world-hit first by the slowdown in China and then in the advanced economies, and subsequently by the spread of the virus. ${ }^{1}$ The paper next summarises what we know of the global economic impact of the COVID-19 pandemic, how it differs to the GFC, and the macroeconomic responses to date (Section 2). We note that the COVID-19 crisis is very different to financial crises such as the GFC and the 1998 Asian financial crisis which were mainly demand shocks requiring resolution of financial system failures. The pandemic consists of both supply-side disruption-consequent on efforts to suppress the transmission of the virus-as well as a demand shock. Discussion then

\footnotetext{
${ }^{1}$ We follow the World Bank in using the LICs and MICs terminology, and the IMF in using the 'advanced economies' terminology.
} 
turns to world commodity markets, including oil and metals and the vital trade in international food commodities. The paper then examines the role of public health and economic and social support in determining the macroeconomic outcomes of the pandemic and the tension between virus suppression and the need to maintain livelihoods (Section 3). Reducing that tension depends on the fiscal space available to LICs and MICs, which need to avoid currency and debt crises as well. We discuss the financing requirements of these policy tasks in Section 4. The paper provides, in Section 5, our observations on possible structural changes in economies resulting from the pandemic, the distributional impact, and the nature of the eventual economic recovery. We conclude by emphasizing the danger that the pandemic poses in reinforcing the existing trend towards higher social inequality.

\section{The global economic impact of the COVID-19 pandemic}

\subsection{Financial crises versus pandemic crises}

The COVID-19 crisis differs fundamentally from the GFC of 2008-09. The GFC began in the financial system after years of overleverage. The COVID-19 crisis began in the real economy, as people fell ill and as China followed by the rest of the world took action to suppress the spread of the virus, leading to the disruption and shutdown of economic activity. ${ }^{2}$ The COVID-19 crisis came on much faster than the GFC, which took a year to develop fully as the first outbreak of financial stress in 2008 spread through the financial system. Prior to 2008, there were many early warning signs for policy makers (which they mostly ignored, unfortunately), while there was no steady accumulation of warning signs of the pandemic for economic policy makers (though the Asia region's experience in containing the 2003 SARS-CoV epidemic at least prepared its health officials). ${ }^{3}$ The GFC transmitted itself from the financial system into the real economy-with bank runs and credit stops resulting in recession and job losses. The COVID-19 crisis runs in the opposite direction via lost income and revenues among households and enterprises; these result in debt defaults that impact on lenders (and into a financial system still operating in the low interestrate environment created by central bank responses to the GFC). ${ }^{4}$

A pandemic results in a domestic-demand shock, compounded by external-demand shocks as outbreaks occurring in the rest of the world spill over via contractions in trade, capital, and remittance flows. Countries with interconnected supply chains experience the largest spillovers. The pandemic disrupts highly integrated global supply chains, which are now a much larger share of world trade than in 2008-09. The economies most interlinked to China suffered the largest firstround impacts. They exceed those in the 2003 SARS outbreak when China accounted for 3 per cent of global GDP compared to 18 per cent today. ${ }^{5}$ Consequently, WTO expects the trade slump

\footnotetext{
2 In its latest (April 2020) assessment, the World Bank projects China's growth for 2020 to decline to 2.3 per cent in the baseline scenario, and 0.1 per cent in the lower-case scenario, from 6.1 per cent in 2019 (World Bank 2020a).

${ }^{3}$ The speed of the onset of the COVID-19 crisis is demonstrated by comparing the IMF's update (of 20 January 2020) of its World Economic Outlook projections (https://www.imf.org/en/Publications/WEO/Issues/2020/01/20/weo-update-january2020), in which there is no mention of COVID-19, and reports prepared for the Spring Meetings 2020 (https://www.imf.org). These meetings were virtual for the first time in the Fund's history.

4 The Federal Reserve Bank of St. Louis provides a dashboard for tracking COVID-19's economic impact in the United States: https://research.stlouisfed.org/dashboard/49765.

${ }^{5}$ Raga and te Velde (2020) provide measures of economic vulnerability to COVID-19, including the impact of the China slowdown.
} 
to exceed that of the GFC. ${ }^{6}$ Tourism earnings have also shrunk, and remittances to LICs and MICs are down by 20 per cent. ${ }^{7}$

The various global models provide rough estimates of the scale of the external shock. On average, spillovers amplify domestic shocks by around 60 per cent in the NIESR ${ }^{8}$ global model: if all countries in the world experienced a 1 per cent domestic shock then the global economy would contract by 1.6 per cent after spillovers. ${ }^{9}$ Country variations around this average then depend on trade-to-GDP ratios and other dimensions of global interconnection as well as policy responses adopted.

In the pandemic's first months, the external-demand shock was far more important to the LICs and MICs than any domestic-demand shock, as they had very few if any outbreaks of the virus (and the reported numbers in many LICs are still low, if the statistics are trustworthy, though they are now high in Latin America's MICs and especially high in Brazil). This is similar to the firstround impact of the GFC, which originated in the financial systems of the advanced economies, not in those of the developing world. Now the LICs are seeing the first domestic economic shocks with the virus spreading and suppression measures established. Inevitably the early spillover impacts onto their economies from China and the advanced economies make it harder for the LICs and MICs to deal with the pandemic as public finances and currencies are already are under strain (as we discuss later in more detail).

The pandemic constituted an immediate supply shock to China and then, as it spread, to Europe, Australia and the United States. Shutting down economic activity is an inevitable outcome of suppression of the virus as businesses close and as movement falls. In contrast the GFC was principally a demand shock, rather than a supply shock in its first years. ${ }^{10}$ However, the GFC did depress supply in the long run by lowering investment and by reducing the potential output of economies below their pre-crisis trend. ${ }^{11}$ Pandemics and financial crises are similar in that pessimistic narratives build up around the prospects for the economy, which in turn depress investment. ${ }^{12}$ Thus the pandemic's long-run impact on the supply side could well exceed that of the GFC, because of what Keynes — writing in the midst of the Great Depression-termed 'animal spirits'.

Finally, the loss of potential output will make the management of the public finances harder as tax revenues are permanently lost, and debt ratios will reach record levels. Finance ministers are currently popular as they make extraordinary spending announcements that break their prepandemic deficit and debt commitments. There will, however, be anguish once policy starts reining in spending. In sum, while policy makers need to deal with the pandemic's immediate macroeconomic impact, they will also have to keep an eye on the future and the post-pandemic recovery.

\footnotetext{
${ }^{6}$ WTO (2020).

${ }^{7}$ World Bank (2020b).

${ }^{8}$ National Institute of Economic and Social Research.

${ }^{9}$ Holland and Liadze (2020).

${ }^{10}$ Cerra and Saxena (2017).

11 Many observers have blamed this legacy of the GFC for the low-productivity growth of the last decade in the advanced economies.

12 Shiller (2017) analyses the spread of narratives about the economy using an epidemiological model.
} 
Our focus is on LICs and MICs. Yet, to understand their situations we must also consider the advanced economies as their macroeconomic responses to the pandemic fundamentally affect the global flows of trade and finance governing the fortunes of the developing world. ${ }^{13}$

Among the macroeconomic tools, monetary policy was the first responder as central banks reached for their GFC toolkit to limit stress in the financial system. The US Federal Reserve resumed quantitative easing in Q1-2020 and is purchasing commercial paper and corporate bonds in order to compress yields and maintain debt financing for companies. ${ }^{14}$ Monetary easing has thereby reduced the rise in spreads on emerging market debt (while EM debtors are downgraded and their new sovereign and corporate issues are much reduced). However, the potency of monetary tools in advanced economies is limited as rates were still near their historic lows at the pandemic's start (and economists once again debate 'helicopter money' as they did in the GFC).

Monetary policy's role is to ensure that lenders extend credit and finance investment, while fiscal policy takes up the heavy lifting-depending on how much of an increase in public debt can be borne-with more funding of public health services, direct support to enterprises in distress, and consumption support for households. One important difference between the pandemic and the GFC is that fiscal policy has a bigger role to play in sustaining the economy's supply side, for a pandemic causes a much greater hit to supply, not least through the destruction of a portion of the labour force as well the shutdown of otherwise viable businesses. We return to this point in Section 3, and now turn to the macroeconomic situation of the advanced economies and China as this is of critical importance to the developing world.

COVID-19 has turned US policy makers into Keynesians_on a scale unimaginable in the 200809 GFC when there was initial hesitancy and legislative opposition. ${ }^{15}$ The fiscal stimulus quickly agreed by the Trump administration and Congress in late March amounts to 10.7 per cent of GDP (a US $\$ 2$ trillion fiscal package versus the GFC fiscal package of US $\$ 800$ billion or 5 per cent of GDP, which started in early 2009). The US ended 2019 with a fiscal deficit of around 4.5 per cent of GDP. ${ }^{16}$ It could end 2020 at around 18 per cent. The US stimulus is unprecedented in peacetime, as is the jump in US debt ratios. The IMF expects debt/GDP for the advanced economies to reach a peacetime record of 122 per cent by end $2020 .{ }^{17}$

The Eurozone's fiscal deficit is expected to reach 15.4 per cent of GDP by end-2020, up from 5.8 per cent at end-2019, according to the IMF. ${ }^{18} \mathrm{EU}$ member states have been arguing about the size of the fiscal recovery package and related European Central Bank measures. Meanwhile forecasts for the contraction in the Eurozone area economy are in the range of 5 to 12 per cent of GDP,

\footnotetext{
13 The IMF provides a country tracker of (macro) policy responses to COVID-19: https://www.imf.org/en/Topics/imf-and-covid19/Policy-Responses-to-COVID-19.

${ }^{14}$ Because of Basel 3, global banks are stronger at the start of this crisis than in 2008-09. Nevertheless, financial stress is evident in the non-bank financial system (NBFS) of advanced economies, a concern for the monetary authorities. In addition, India's NBFS could be a source of systemic banking crisis as borrowers default.

15 In the US in 2009, many economists argued for a bigger fiscal stimulus than 5 per cent of GDP, but Congress opposed this. Fiscal austerity characterized the years subsequent to the 2008-09 GFC as northern Eurozone governments and the UK government sought to bring down fiscal deficits and debt/GDP levels, a misreading of the causes of the GFC (which was sparked by a massive bank-run rather than by government over-borrowing).

${ }^{16}$ IMF (2020b: 6: Table 1.1). The IMF’s measure is the General Government Fiscal Overall Balance.

${ }^{17}$ IMF (2020b: 7: Table 1.2).

${ }^{18}$ IMF (2020b: 6: Table 1.1). See also Gourinchas (2020: 31-39).
} 
depending on the success of the pandemic's containment. The Eurozone danger is a debt crisis in Italy which would be on a far bigger scale than Greece in the aftermath of the GFC, and would likely spread contagion across global bond markets, further eroding the ability of LICs and MICs to finance their own pandemic strategies.

China's massive fiscal and monetary stimulus of 2008-09 helped shore up the global economy during the GFC (and China's own growth barely dipped; it was 9.1 per cent in 2009, a year after the GFC began). ${ }^{19}$ Can China act as a locomotive for the global economy again? China's fiscal injection was about 1.2 per cent of GDP (US $\$ 180$ billion) initially on top of a fiscal deficit of 6.4 per cent of GDP at end-2019; there is more to come (including by local authorities) and the IMF projects a deficit of 11.2 per cent for $2020 .{ }^{20}$ China's debt ratios were much higher at the beginning of COVID-19 than at the start of the 2008-09 GFC when it had more room for fiscal stimulus (amounting to US $\$ 590$ billion, around 12.5 per cent of GDP). And whereas China's monetary stimulus in the GFC exceeded that of the US, the Fed is today more aggressive than the PBOC $^{21}$ (which is more cautious than in the GFC as it is still dealing with the legacy of the GFC monetary stimulus on the domestic financial system). ${ }^{22}$ Still, China has a much bigger share of world GDP than it did in the GFC years.

Therefore, China can act as one global locomotive, though not on the scale of the GFC years. China is starting to get back to work; large industries operate, and about three-quarters of SMEs are open even if working below capacity. Yet, China's retail and entertainment economies are still down, and household savings rates have jumped-making a large recovery in consumer spending (beyond basic necessities) unlikely unless the authorities commit to large direct transfers to households. In their absence, China's recovery is more dependent on external demand (whereas in recent years policy has been rebalancing the economy towards domestic consumption as a motor for growth). Importantly, the rest of the world is now slowing China down, and the recoveries of the US, Europe and the rest of Asia will be critical to the depth and duration of China's recession and the pace of its eventual recovery. However, household savings rates are also rising in the rest of world and unless this proves temporary, China will struggle with its exports.

With household consumption depressed, and private investment slumping, governments must be expansionary to sustain aggregate demand. Stimulus in the advanced economies as well as China, India and the other big emerging economies reduces the size of spillovers on the smaller LICs and LMICs, which are highly open economies. Even so, the negative spillovers are still large, and the WTO is forecasting a 2020 slump in global trade of between 13 per cent (the 'optimistic' scenario) and 32 per cent (the 'pessimistic' scenario). ${ }^{23}$ UNCTAD expects that developing countries (excluding China) will lose US $\$ 800$ billion in export revenues in $2020 .^{24}$

Sub-Saharan Africa (SSA) will experience its first recession in 25 years, with growth turning negative in 2020 , in the range of -2.1 to -5.1 per cent (down from 2.9 per cent in 2019), according

\footnotetext{
19 Wong (2011).

${ }^{20}$ China's official budget deficit estimate is about half the size of the IMF's estimate which tries to account for the (many) off-budget activities: see BOFIT (2020).

21 People's Bank of China.

${ }^{22}$ For China, one legacy of the monetary stimulus of the GFC years is a large shadow banking system, which the PBOC has been squeezing by keeping rates relatively high to encourage depositors into the formal financial system. Local governments and state-owned companies are also heavily indebted.

${ }^{23}$ WTO (2020).

${ }^{24}$ UNCTAD (2020a: 8).
} 
to World Bank estimates. ${ }^{25}$ The IMF is projecting SSA's GDP to shrink by 1.6 per cent in 2020 (with South Africa's GDP contracting by nearly 6 per cent). ${ }^{26}$ In addition to the direct effect of the virus on economic activity in SSA, there is the hit to most commodity prices (discussed later), the disruption in export supply, loss of tourism income, falling remittance flows, and a contraction in commercial finance (bond issuance is very limited) and capital outflow.

Given the pandemic's economic fallout, it is vital to find more fiscal space to fund public health together with economic and social support. The advanced economies have more fiscal firepower at their disposal than the MICs, while the LICs have the least. ${ }^{27}$ In Africa, announcements of economic stimulus packages average 0.8 per cent of GDP, compared to 8 per cent of GDP for the average stimulus package in the developed world. ${ }^{28}$ South Africa is the exception, with a stimulus of about 10 per cent of GDP. Loan guarantees for companies accounted for the major share with more modest spending increases around 3 per cent of South Africa's GDP. SSA has limited fiscal space to use to offset the shock, and needs much more external financing to get through the pandemic.

\subsection{Poverty and human development impact}

Simulations by the Imperial College COVID-19 Response Team find that ' $\ldots$ in the absence of interventions, COVID-19 would have resulted in 7.0 billion infections and 40 million deaths globally this year'.29 Interventions range from mitigation (protecting at risk groups and slowing but not supressing the virus' transmission) to suppression (via 'lockdowns', enforced social distancing, and quarantines). Many of these deaths can be expected to occur among poor people, as they often have pre-existing health conditions, are undernourished, and have few resources to cope. At the same time, mitigation and suppression, together with the global economic slowdown, reduce their incomes even further.

Simulations of the pandemic's impact show dire consequences for human development and global poverty. Simulations of the impact of the GDP fall and its income-poverty effect, together with the rise in ill-health and mortality and the decline in effective education due to school closures, will result in the first decline in UNDP's Human Development Index (HDI) since it was introduced 30 years ago; the expected fall wipes out the last six years of global progress in human development (UNDP 2020a: 6).

The impact on gender equality will be severe, as women are often disproportionately found in the least well-paid occupations, often in part-time and seasonal work-alongside their many household responsibilities including family healthcare-and in occupations with the least employment protection or social security entitlement (many women are in informal employment as well). ${ }^{30}$ The closure of schools and day nurseries may force women to withdraw from

\footnotetext{
25 World Bank (2020a: 1).

${ }^{26}$ IMF (2020c; v). The largest contractions in the IMF's SSA forecasts are in Nigeria (-3.4 per cent) and South Africa (-5.8 per cent). For South Africa, Arndt et al. (2020: 22) estimate a 5 per cent contraction by end-2020 even in the best ('quick recovery') scenario.

27 On Latin America, see Chang and Velsaco (2020), Hevia and Neumayer (2020). The downturn in commodity prices has severely affected Latin America's fiscal position.

28 UNECA (2020).

${ }^{29}$ Imperial College COVID-19 Response Team (2020: 1).

${ }^{30}$ In poorer countries, recessions typically have a disproportionate impact on women's employment as women tend to work in jobs and sectors with the least job protection. In contrast, men's employment is more adversely affected than women's in the 'typical' US recession (Doepke and Tertilt 2016: 1816). However, in this pandemic recession
} 
employment. Postponement of health care treatment and services for family planning, pregnancy, and new mothers will add to maternal mortality. In times of economic stress, girls are often the first to be withdrawn from school (or to miss classes) as they substitute for working mothers, leading to lower female educational attainment and worse long-term employment and earnings prospects.

Sumner et al. (2020) simulate the effect on global income-poverty (with three poverty lines) of three scenarios of national income/consumption per capita contractions of 5 per cent, 10 per cent, and 20 per cent. ${ }^{31}$ All three scenarios result in the global poverty head-count rising for the first time since 1990:

In absolute terms, these changes mean that the number of people living in poverty in the world could increase, in comparison to the status quo in 2018, by between $85-135$ million under a 5 per cent contraction, by between 180-280 million under a 10 per cent contraction, and, startlingly, between $420-580$ million people under a per capita income or consumption contraction of 20 per cent (Sumner et al. 2020: 5-6).

Most households in LICs, and many in MICs, do not have the savings nor the regular employment to secure their food needs, and without transfers, hunger will rise. ${ }^{32}$ Some 135 million people were already in acute hunger before the impact of COVID-19—-many being in conflict countries—and this number could rise to 265 million in 2020 in the latest forecasts from WFP and others. ${ }^{33}$ Much depends on outcomes for national and global food markets. Running IFPRI's global model with a scenario of a 5 per cent fall in global GDP in 2020 (leading to a drop in SSA's GDP of nearly 9 per cent) and incorporating disruption to agricultural supplies, Laborde et al. (2020) find that 140 million additional people could fall into extreme poverty in 2020 - a 20 per cent global increase. This includes 80 million in Africa and 42 million in South Asia increase. We return to food security later in the paper.

\subsection{Deflation versus inflation}

Major central banks are for now revising downward their inflation expectations-which were already low at the start of 2020 — as the global economy enters recession and as oil prices fall to levels last seen around the millennium. ${ }^{34}$ Japan risks slipping back into deflation, as does Europe. Deflation would magnify the pinch on enterprises since consumers are already delaying purchases until the pandemic ends, and the prospect of lower future prices encourages more delay (with companies adjusting by lowering nominal wages, thereby exacerbating the stagnation of consumption). Deflation also magnifies debtor distress as the real cost of debt service rises.

social distancing measures and the closures of schools and nurseries disproportionately impacts women's employment in the US (Alon et al. 2020).

31 The IMF's World Economic Outlook for 2020, released in April, forecasts contractions of output per capita at 2.4 per cent for emerging markets and developing economies and at 1.8 per cent for low income developing economies in 2020 (IMF 2020a).

32 See Chen (2020) on the plight of informal workers during the pandemic. Many workers are day labourers: if they do not work, they do not eat. Gentilini et al. (2020) provide a real-time tracking of progress in expanding social protection to meet the demands of COVID-19.

${ }^{33}$ GNFC (2020: 2).

${ }^{34}$ China was an exception at the start of 2020, with 5 per cent inflation, as an animal pandemic (swine flu in pigs) gave a jolt to food price inflation in 2019. China's inflation rate has now fallen to around 3 per cent. 
Inflation might return if recovery begins in 2021, including a bounce-back in the oil price. ${ }^{35}$ Glimmers of recovery might then encourage policy makers to start reversing the stimulus. It is critical to get the timing of the stimulus right: premature tightening runs the risk of stalling recovery (as it did after the GFC). Policy makers must therefore steer a difficult course. Central banks should set themselves higher inflation targets since deflation, once established, is harder to eradicate than inflation. ${ }^{36}$ The coming decisions of the Fed, the ECB, and the PBOC will fundamentally affect the prospects of the LICs and LMICs as deflation in the large economies risks transmission to commodity producers, as happened in the 1930 s Great Depression. ${ }^{37}$

Even though inflation measures are trending lower, price spikes in key goods remain likely (as well as outright market stops). Price volatility will rise as markets thin out, consequent upon supplychain disruption as well as an increase in export bans, 'piracy' (diverting supplies away from already agreed contracts), and a surge in air freight rates. ${ }^{38}$ The LICS and LMICs with the least manufacturing capacity are vulnerable to supply shortages, price hikes in imported medical supplies and drugs, and to being out-bid. ${ }^{39}$ Food-supply shortages may lead to rationing and/or to higher food price inflation (discussed later in the paper). When food has a high share in the baskets used for inflation measures, central banks must be wary of responding with monetary tightening to any pick-up in inflation, for the solution to food price inflation lies on the supply side-including maintaining an open trading system — and in defeating the virus itself.

On the supply side, the structure of production is altering. Some of this intended (a rise in the output of critical healthcare inputs) and much is an indirect consequence of virus suppression (a contraction in retail and leisure services) thereby releasing labour and capital, some of which is redeployed into the expanding activities. ${ }^{40}$ Nevertheless, critical shortages in specialized skills and equipment could dampen the supply responses in key sectors, leading to price rises and/or rationing (to which the LICs are most vulnerable as they have the least purchasing power in global supply chains).

\subsection{The scale of the commodity-price shock in the developing world}

Price shocks in world commodity markets (also evident in the 2008-09 GFC) and disruptions to commodity supplies and trade (not a feature of the GFC) are especially important for the developing world. Within SSA, growth has taken the biggest hit in countries dependent on large extractive sectors. The World Bank estimates that growth in 2020 could fall by up to 7 percentage points in oil-exporting countries and by more than 8 percentage points in metals exporters

\footnotetext{
35 Blanchard (2020) discusses the prospects for inflation, including the role of debt-dynamics in the context of recurrent outbreaks.

36 Posen (2020: 205) recommends strengthening the policy signal through a joint announcement by central banks of higher inflation targets.

${ }^{37}$ On the depression of the 1930s and its impact on commodity producers see Bernanke (2004: 110) and Kindleberger (1973).

38 For monitoring of export restrictions, see https://www.globaltradealert.org. As of March, more than 50 governments had imposed curbs or bans on the export of medical supplies, including much-needed facemasks and ventilators. Airfreight rates have soared as airlines cut back passenger flights, leaving less cargo capacity, with more emergency medical supplies being transported by air instead of in container ships.

${ }^{39}$ Importers could also help themselves by eliminating tariffs on essential imported supplies, including that most basic but useful health-input: soap (Evenett 2020).

${ }^{40}$ Baldwin (2020) provides a framework for analysing structural change resulting from the pandemic and responses to it.
} 
(compared with the no-COVID base case). ${ }^{41} \mathrm{New}$ investment in mining and oil and gas is also contracting, as multinational companies revise their earnings expectations downwards and cut their Capex. $^{42}$

Most base metals prices fell sharply in Q1-2020 as expectations of global growth slumped, hitting demand for copper, aluminium and nickel (China is the biggest market for many metals). The IMF expects a fall in metals prices of 15 per cent in 2020, and 5.6 per cent in $2021 .{ }^{43}$ The copper price reached its January 2016 level (the last cyclical bottom) by mid-March $2020 .{ }^{44}$ This is bad news for the big copper exporters, Zambia and Chile. Iron ore's price has held up better than copper-on hopes that China's stimulus will feed into steel production and construction-and is now above its mid-2019 level. Gold, a safe haven in times of financial crisis, is the exception among the metals, and reached a 7-year high in April. ${ }^{45}$ During the Ebola outbreak of 2014-16, mine closures in West Africa hit export earnings, tax revenues and the local economies in mining areas. We expect similar impacts now.

Oil has seen the biggest price fall among the commodities. The global benchmark price (Brent crude) sank to US $\$ 21$ a barrel by 21 April, down by more than two-thirds over the quarter, reaching its early 2002 level (it was at US $\$ 70$ this time last year). Falling Chinese demand pushed the price down, and the fall accelerated with the failure of OPEC + to agree a production-cut deal on 6 March (agreement was finally reached on 12 April, but the oil market continues to weak, though the Brent price has recovered to US $\$ 38$ as of early June). ${ }^{46}$ Oil's collapse also dragged down the price of many contracts for liquified natural gas (LNG). ${ }^{47}$ However, prices for gas are firmer than for oil as the downturn in travel has hit oil demand, while gas has a rising share in electricity generation. The drop in prices for oil and gas is a big fiscal shock for net oil exporters (see later discussion). However, oil importers will see considerable savings in their import bills from the lower price. ${ }^{48}$

The shutdown in production may result in much higher oil prices next year if the global economy recovers strongly and inventories are low by then. ${ }^{49}$ Central banks closely watch the oil pricewhich is important to global inflation-and any shortage-driven oil price spike in 2021 could pose

\footnotetext{
${ }^{41}$ Calderon et al. (2020: 1).

42 UNCTAD (2020b).

${ }^{43}$ IMF (2020a: 5).

44 Many base metals were already weakening prior to the onset of COVID-19 ('Dr Copper' was signalling a global slowdown by mid-2019).

45 Though the gold price has been highly volatile, reflecting 'risk-on, risk off trading. Prices for some rarer metals, such as uranium and cobalt, are up as mines reduce output or close temporarily as mining companies cope with the pandemic. Cobalt hydroxide prices have risen on worries about supply disruptions in the DRC's mines, which account for over 60 per cent of world supply, and port closures in South Africa, which handle much of the shipment.
}

46 The 12 April agreement was for one of the largest production cuts in OPEC's history. It pushed the Brent price up to US\$32 a barrel, but there were immediate doubts about its sticking power, and subsequently the US oil price (West Texas Intermediate) turned negative on 20 April, as storage ran out.

${ }^{47}$ Many LNG contracts in Asia are linked to the oil price. Chinese importers have also invoked force majeure on LNG cargos, and may seek to renegotiate long-term contracts to achieve lower prices.

48 This includes countries that not only import all their oil (e.g. Rwanda and Zambia), but also oil-importing countries (e.g Kenya, Mozambique, and Tanzania) which export gas (or expect to), but which import oil, and Uganda a future net oil-exporter but a current net oil importer.

${ }^{49}$ Some oil production may never return as it is expensive to restart production, and Africa's deep-water oil producers such as Angola need a high price to cover their high production costs. 
a dilemma for monetary policy when focused on minimizing the recession. Stagflation is the worst scenario for central banks to deal with.

\subsection{Food price shocks}

Price volatility will increase in commodity markets as inventories run down, and as markets become more thinly traded as supplies diminish. Agricultural commodities are of special concern, for reasons of food security. Sickness and social distancing among agricultural workers reduce food production, with labour-intensive crops being the most vulnerable. The 50 countries most affected by the pandemic account for around two-thirds of the world export supply of food products. ${ }^{50}$ Moreover, transport, both domestic and international (airline cargo and shipping) is disrupted by the pandemic, together with supplies of fertilizers and pesticides (also reflecting disruption to manufacturers of agricultural inputs).

Some rice and wheat exporters suspended signing new export contracts in Q1-2020 while they built their own national stocks. ${ }^{51}$ This set alarm bells ringing in international food markets. During the 2006-08 price spike, nearly half of the rise in the rice price, and around one-third of the wheat price-increase, was due to export bans (which were also used in the 2010-11 price spike).$^{52}$ Export bans, by thinning out international grain markets, make national food security more vulnerable to domestic food-shocks, including droughts and floods (whose frequency has risen with climate change) and pest attacks. ${ }^{53}$ Export restrictions and other distuption to international trade in food also increase the difficulty (and cost) of humanitarian assistance in war zones and in natural disasters. ${ }^{54}$ Simulations of disruptions to global food markets under scenarios for COVID-19 and policy responses such as export bans, highlight the sensitivity of poverty estimates to food price shocks. ${ }^{55}$

Fortunately, the production of major staples and their stocks have been high in recent years, and global price levels have been relatively stable up to end-2019 (helped by low fuel prices). The current global food supply situation is therefore better than in earlier price spikes (though on the demand side, there is a similarity to 2009-10 which was also a period of unprecedented monetary expansion in the advanced economies; this then amplified food price inflation). ${ }^{56}$ While the benchmark Thai rice price rose 20 per cent over Q1-2020, export restrictions introduced in March were reversed by May as national quotas for rice were quickly filled (as they were for wheat which

\footnotetext{
${ }^{50}$ Espitia et al. (2020).

${ }^{51}$ Russia, the world's leading wheat exporter, restricted the export of buckwheat in April (Ukraine, also). EUI-GTAWB (2020) provides a COVID-19 trade policy database covering both food and medical supplies: https://www.worldbank.org/en/topic/trade/brief/coronavirus-covid-19-trade-policy-database-food-and-medicalproducts.print.

52 Martin and Anderson (2011). On the last round of global food price shocks, see Pinstrup-Andersen (2014). The food crisis interacted with the GFC, see Arndt et al. (2020).

${ }^{3}$ East Africa is expecting a second wave of desert locusts, far larger than the February 2020 outbreak, which was itself the worst in 70 years. See FAO's Locust Watch: http://www.fao.org/ag/locusts/en/info/info/index.html.

${ }^{54}$ The Yemen, for example, imports nearly all of its food, even in years without war. The implementation of COVID19 protective measures at food distribution sites has slowed down World Food Programme's food distribution in Yemen and Syria (WFP 2020a, 2020b).

55 See the simulations of the IFPRI global model by Laborde et al. (2020) referred to earlier.

56 The global price spikes of 2006-08 and 2010-11 partly cross over the period when monetary policy in the advanced economies was exceptionally expansionary in response to the GFC (Addison et al. 2011). There is a debate about how much of this ample liquidity spilled over into commodity markets, exacerbating price movements (Tadesse et al. 2014). 'Financialization' has deepened the linkages between financial and commodity markets through the creation of instruments such as exchange traded funds (ETFs).
} 
so a small international price rise) ${ }^{57}$ The international maize price fell in the first half of 2020 due to reduced demand for both animal feed (as demand for meat fell with restaurant closures) and biofuel production; FAO is anticipating strong maize production this year. ${ }^{58}$ Moreover, we have yet to see-and hopefully may not - a large rise in morbidity rates in SSA, where smallholder agriculture is very labour-intensive. Indeed, smallholders may see more demand for any surpluses they produce as currencies are weakening, thereby reducing the demand for imported food. Maintaining smallholder production is a priority not just to contain any rise in rural poverty arising from the pandemic, but also to maintain domestic food supplies-including to urban centres.

Importing countries are increasing their strategic grain stocks (North Africa's imports have surged), given their memories of the last global food price spikes, of 2006-08 and 2010-11. ${ }^{59}$ However, many LICs do not have enough foreign exchange to cover additional, and now more expensive, food imports. The loss of export earnings, tourism and remittances causes currencies to depreciate which passes through to domestic food prices in net food-importing countries and makes essential agricultural inputs, such as pesticides and animal vaccines, more expensive. It will take generous international financial support to prevent a deterioration in food security.

Moreover, food supply stress and high prices typically result in social instability. The price spikes of more than a decade ago were one catalyst for the protests that initiated the 'Arab Spring' (or the 'Hunger Revolution' as it was known locally). ${ }^{60} \mathrm{In}$ sum, the picture is somewhat less worrying than at the start of the pandemic. Nevertheless, the global food situation is one to keep an eye on, not just for the poverty impact, but also for its macroeconomic consequences as well as for its consequences for social stability.

\section{$3 \quad$ Public health and economic and social support}

\subsection{Lives versus livelihoods?}

To strike successfully the balance between minimizing loss of life and minimizing the damage to the economy and the social fabric requires a package of public health $(H)$ measures, together with economic and social support (ESS) to households and enterprises. Tables 1 and 2 provide an overview of the main possible components of H-ESS, with the proviso that what is feasible depends on national human, organization and financial resources and the generosity (or not) of international assistance. We reemphasize the point, made earlier, that fiscal policy's role in maintaining the supply-side of the economy is greater in a pandemic than in financial crises such as the GFC, given the former's larger impact on human health (and therefore the labour supply) and in closing down otherwise viable businesses.

\footnotetext{
${ }^{57}$ Our picture of the current state of global food markets was improved by the launch of AMIS (Agricultural Market Information System) in 2011, a G20 response to the 2006-08 and 2010-11 price spikes: http://www.amisoutlook.org/amis-monitoring/monthly-report/en. The United States Department of Agriculture monthly World Agricultural Supply and Demand Estimates are also available: https://www.usda.gov/oce/commodity/wasde/.

${ }^{58}$ FAO (2020).

${ }^{59}$ Food price inflation is a particular concern for China's authorities, as food accounts for a large weighting in the indices. China's food price inflation was already high pre-pandemic, a consequence of swine flu in pigs. Parts of China's food-supply chain are very import dependent (imports account for 85 per cent of China's soybean consumption), and highly vulnerable to supply disruptions in Latin America, China's main soybean supplier.

${ }^{60}$ Bellamare (2014) finds robust evidence of food price increases causing social unrest to rise for the period 1990-2011.
} 
Table 1: H-ESS package: public health components

\begin{tabular}{|c|c|}
\hline Measures & Observations (modalities, requirements, constraints) \\
\hline $\begin{array}{l}\text { Personal protective } \\
\text { measures (hand-washing, } \\
\text { respiratory etiquette). }\end{array}$ & $\begin{array}{l}\text { Communication of advice from public health authorities via all available } \\
\text { media. } \\
\text { Requires supplies of soap and other cleaning materials to be made } \\
\text { available, especially in poor communities, upgrading of toilets and other } \\
\text { sanitation facilities. } \\
\text { Provision of masks and gloves to the general public, either imported or } \\
\text { manufactured locally. In extremis, recycling. }\end{array}$ \\
\hline $\begin{array}{l}\text { Physical distancing and } \\
\text { travel-related measures }\end{array}$ & $\begin{array}{l}\text { Physical distancing measures apply to individuals (isolation of cases and } \\
\text { quarantining of their contacts) or to specific communities with outbreaks, } \\
\text { specific segments of the population (e.g the most vulnerable), or to the } \\
\text { population as whole. Requires ability to house, feed and take care of } \\
\text { vulnerable people while shielded. } \\
\text { Voluntary compliance vs compulsory compliance (depending on capacity of } \\
\text { authorities to enforce rules and the provision of social protection to reduce } \\
\text { the need of people to break rules to maintain their livelihoods) } \\
\text { Clear and consistent message by national and local leadership. Credible } \\
\text { messaging, supported by the personal behaviour of leaders delivering the } \\
\text { messaging. Mobilizing community and religious leaders and respected } \\
\text { social influencers for messaging. } \\
\text { Use of behavioural science (but taking account of local culture and norms) } \\
\text { to nudge adoption of desirable behavioural responses (and discourage } \\
\text { undesirable ones). } \\
\text { Epidemiological surveillance, other data analytics to inform decisions at } \\
\text { national and local levels, and modelling capacity to make projections and } \\
\text { create scenarios and assess alternative public health interventions (e.g in } \\
\text { light of the evolution of 'R' variable) }\end{array}$ \\
\hline $\begin{array}{l}\text { Identify, isolate, test, treat } \\
\text { cases, to break the chains of } \\
\text { transmission }\end{array}$ & $\begin{array}{l}\text { Laboratory capacity created to deliver fast and reliable test results at scale. } \\
\text { Personal Protective Equipment (PPE) available and widely distributed, inc. } \\
\text { to clinics in poor communities and rural areas. } \\
\text { Clinic and Hospital capacity (inc. admissions and discharges as well as ICU } \\
\text { and non-ICU beds, ventilators, oxygen supply and drugs). Enhanced } \\
\text { training for triage at clinics and hospital admissions. } \\
\text { Antibody testing at scale (when tests developed and available). }\end{array}$ \\
\hline $\begin{array}{l}\text { Trace and quarantine } \\
\text { contacts }\end{array}$ & $\begin{array}{l}\text { Existing professional contact-tracers and trained volunteers. Phones, fax } \\
\text { machines, computer equipment and contact-tracing software (and training } \\
\text { in use of). } \\
\text { Adoption of Blue-tooth contract-tracing apps (if reliable) for personal } \\
\text { cellphone and if the public is willing to adopt them (and if mobile phone } \\
\text { penetration in LICs is high enough). Ensure data privacy. }\end{array}$ \\
\hline $\begin{array}{l}\text { Additional large-scale public } \\
\text { health and social measures } \\
\text { (PHSM) }\end{array}$ & $\begin{array}{l}\text { PHSM includes: movement restrictions, closures of schools, business etc., } \\
\text { geographical area quarantine, and international travel restrictions } \\
\text { (commonly referred to as 'lockdown' or 'shutdown' measures). } \\
\text { Risk assessment of the benefits and harms arising from PHSM, both its } \\
\text { introduction, any loosening as cases decline, and its reintroduction if } \\
\text { additional patient load threatens to surge beyond the capacity of the health } \\
\text { system to treat patients (WHO } 2020 \mathrm{~d} \text { : } 1 \text { ). Risk assessments are needed at } \\
\text { national, regional and sometimes community levels. } \\
\text { WHO guidance is for risk assessment to use the following indicators: (i) } \\
\text { epidemiological factors; (ii) health care capacities; (iii) public health } \\
\text { capacities; (iv) availability of effective pharmaceutical interventions (WHO } \\
2020 d \text { : 2). } \\
\text { Movement restrictions: capacity of police, border force, and other } \\
\text { authorities to enforce restrictions on entry and exit into a region/locality } \\
\text { within a country or travel across national borders. Ability to rapidly detect }\end{array}$ \\
\hline
\end{tabular}




\begin{tabular}{|c|c|}
\hline & $\begin{array}{l}\text { and manage suspected cases at borders inc. ability to quarantine people } \\
\text { from areas with community transmission. Measures to reduce risks to } \\
\text { travellers at ports and airports and while travelling. } \\
\text { Assessment of behavioural responses to restrictions, to gauge compliance } \\
\text { (requiring consideration of the economic and social factors that may lead } \\
\text { individuals to break restrictions to maintain livelihoods). }\end{array}$ \\
\hline $\begin{array}{l}\text { Maintain preventative health } \\
\text { care measures }\end{array}$ & $\begin{array}{l}\text { Especially vaccinations for polio, measles etc. Contain and manage } \\
\text { outbreaks of other diseases (especially. malaria, dengue, TB). Requires } \\
\text { sufficient medical and other personal to maintain vaccinations while } \\
\text { increasing COVID-19 response. } \\
\text { Add capacity in health system to treat COVID-19 patients while maintaining } \\
\text { regular health (inc. emergency) services. Create additional capacity for a } \\
\text { 'dual-track' system capable of both. Continue diagnosis and treatment of } \\
\text { minor and major health conditions, if feasible } \\
\text { Community health clinics strengthened. Support to child and maternal } \\
\text { health programmes enhanced, together with nutrition programmes to } \\
\text { contain and reduce malnutrition. }\end{array}$ \\
\hline $\begin{array}{l}\text { Deployment of effective } \\
\text { therapeutics and vaccination } \\
\text { against SARS-CoV-2 }\end{array}$ & $\begin{array}{l}\text { A safe and reliable therapeutics and vaccines if they become available and } \\
\text { can be produced at scale } \\
\text { Vaccination plan: priorities for who is to be vaccinated first. Vaccines } \\
\text { developed in advanced economies and China need to be made available in } \\
\text { LICs and MICs. } \\
\text { Public health campaign to encourage population to take up vaccination. }\end{array}$ \\
\hline $\begin{array}{l}\text { Transition phase out of } \\
\text { pandemic }\end{array}$ & $\begin{array}{l}\text { A transition plan and one that conforms to national and local realities, } \\
\text { including the prospects for the economy and thereby the public finances. } \\
\text { WHO (2020d) recommends six conditions for transition to begin: (i) } \\
\text { evidence shows that COVID-19 transmission is controlled; (ii) sufficient } \\
\text { health system capacity is in place to isolate, test, and treat all cases, and to } \\
\text { trace and quarantine contacts; (iii) outbreak risks are minimized in high- } \\
\text { vulnerability settings (iv) preventative measures are established in } \\
\text { workplaces (v) management of the risk of exporting and importing cases } \\
\text { from communities with high risks of transmission is established (vi) } \\
\text { communities have a voice, are informed and are engaged in the transition. }\end{array}$ \\
\hline
\end{tabular}

Notes: this is by no means a fully inclusive list of all measures. Public health measures are based on WHO guidance: https://www.who.int/emergencies/diseases/novel-coronavirus-2019/technical-guidance.

Source: authors' construction based on WHO (2020a, 2020b, 2020c). 
Table 2: H-ESS package: economic and social support components

\begin{tabular}{|c|c|}
\hline Measures & Observations (modalities, requirements, constraints) \\
\hline Enterprise assistance & $\begin{array}{l}\text { Central banks encourage formal financial system to expand lending to } \\
\text { (formal-sector) enterprises. Subsidized special loan windows with low- } \\
\text { interest rates. } \\
\text { Micro-credit programmes for small and medium enterprises: expansion and } \\
\text { deferment of repayments (depending on the solvency of the microcredit } \\
\text { programme this may require some government subsidy). } \\
\text { PPE for workers and customers: to reduce viral transmission while } \\
\text { businesses continue to produce and serve customers. } \\
\text { Taxation (for formal sector enterprises only): deferral of payments (VAT, } \\
\text { corporation taxes, property taxes etc.) and extension of deadlines for filing. } \\
\text { Exemption for payments for key sectors (e.g priority exporters). Suspension } \\
\text { of property taxes (e.g for small registered businesses). Reduction in VAT, } \\
\text { corporation and other tax rates. } \\
\text { Enterprise assistance confined to registered (tax-paying) firms may } \\
\text { encourage formalization, which has long-term benefits (inc. for revenues). } \\
\text { Any increase in formalization during the pandemic will, however, increase } \\
\text { the financial cost to government of providing the assistance. } \\
\text { Informal enterprises: typically assisted via household income support (see } \\
\text { below). Reduction in utility bills for informal enterprises may be viable. } \\
\text { Reduce market taxes and fees. In general, it is much harder to assist the } \\
\text { informal sector, as for example these enterprises do not pay VAT and are } \\
\text { therefore ineligible for assistance through the VAT system. } \\
\text { International concessional financing and grants: IFC initiatives to expand } \\
\text { financing which can then be used to expand local credit provision to } \\
\text { enterprises. }\end{array}$ \\
\hline $\begin{array}{l}\text { Employer wage subsidies } \\
\text { and other labour market } \\
\text { measures }\end{array}$ & $\begin{array}{l}\text { Wage subsidies to (formal) enterprises to reduce the need to furlough or } \\
\text { fire workers (and therefore the need for severance payments). Maintains } \\
\text { employment relationship, thereby reducing the need for new hiring once } \\
\text { recovery begins (thereby lowering firm hiring costs). } \\
\text { Subsidies for new employment and training and subsidies designed to } \\
\text { facilitate movement of workers from firms temporarily closed due to those } \\
\text { experiencing labour shortages. } \\
\text { General subsidies (all workers in all registered firms) or targeted to specific } \\
\text { sectors (e.g. workers in registered manufacturing firms or tourism or } \\
\text { transport); subsidies paid irrespective of firm size or targeted to micro and } \\
\text { small (registered) firms; subsidies contingent on firm reporting a minimum } \\
\text { decline in revenues or profits or paid without requiring such reporting. } \\
\text { Regular payment as a percentage of worker salary or fixed payment } \\
\text { irrespective of wage level. Sliding scale, with more subsidy for low-paid } \\
\text { workers and payments capped for high-paid workers. Payments linked to } \\
\text { minimum wage (e.g. 50\%). Subsidies for new employment and training. } \\
\text { Extending wage subsidies to temporary workers, who in contrast to } \\
\text { permanent workers are often not eligible for social security payments, and } \\
\text { are not covered by unemployment insurance. Women make up a high } \\
\text { percentage of temporary workers as they are often part-time or seasonal. } \\
\text { Payments to registered self-employed (individual operators e.g. } \\
\text { feelancers). } \\
\text { Active labour market programmes: support to unemployed and furloughed } \\
\text { workers for training, via vouchers or direct training programmes. Targeting } \\
\text { of worst-affected worker groups (e.g. retail) } \\
\text { Informal workers: mainly supported via social assistance to eligible } \\
\text { individuals and households (see below). Provision of training programmes } \\
\text { to informal workers. }\end{array}$ \\
\hline Social insurance & $\begin{array}{l}\text { General public pension increase for all eligible senior citizens or top-ups } \\
\text { confined to low-income pensioners. Earlier pension payments. Social }\end{array}$ \\
\hline
\end{tabular}




\begin{tabular}{|c|c|}
\hline & $\begin{array}{l}\text { security contribution temporarily waived, deferred, or reduced (or } \\
\text { subsidized). Early withdrawal of funds for early retirement (but depends on } \\
\text { solvency of the pension fund). } \\
\text { Increase in disability payments and paid sick support. Unemployment } \\
\text { benefit. }\end{array}$ \\
\hline $\begin{array}{l}\text { Social assistance: cash } \\
\text { transfers }\end{array}$ & $\begin{array}{l}\text { Unconditional and conditional cash transfers; increase in size of payments; } \\
\text { coverage extended, admin reforms to increase efficiency and maximize } \\
\text { benefit to recipients. } \\
\text { Extension of existing cash transfer programmes and one-off COVID-19 } \\
\text { payments. } \\
\text { Expansion of coverage beyond pre-pandemic target group; increase in } \\
\text { (real) benefits; simplification of administration to increase take-up (and } \\
\text { reduce personal contact between administrative staff and people with the } \\
\text { virus). } \\
\text { Cash transfers: earlier payments; more frequent payments; flexibility in time } \\
\text { of collection; waiving of conditionalities; postponement of recertification for } \\
\text { eligibility. } \\
\text { Admin reforms to increase efficiency, reduce admin costs, and encourage } \\
\text { take-up: sharing of administration facilities across different social } \\
\text { assistance programs; shift to digital payments (inc. use of mobile money). } \\
\text { Home delivery of cash for vulnerable groups, such as seniors, who have } \\
\text { difficulty in accessing digital payments; authorization of proxies (e.g. close } \\
\text { relatives) to collect payments on behalf of vulnerable clients. } \\
\text { Universal basic income: either as a 'minimum base' then topped up for low- } \\
\text { income and especially vulnerable groups by other assistance, or as the } \\
\text { main social protection response. }\end{array}$ \\
\hline $\begin{array}{l}\text { Social assistance: workfare } \\
\text { and other assistance }\end{array}$ & $\begin{array}{l}\text { Unconditional or linked to existing workfare programmes, payment in food } \\
\text { or cash. Proceed with caution on workfare as the projects could turn into } \\
\text { hot spots of transmission when they involve large numbers of workers, who } \\
\text { may be safer back in their households when unconditional food is provided } \\
\text { or, preferably, cash transfers. Those with existing workfare programmes } \\
\text { can pay workers without requiring work. } \\
\text { Cash transfers are generally superior (more cost-effective) than food- } \\
\text { transfers, when food-supply chains are functioning normally. If these are } \\
\text { disrupted by the pandemic (inc. necessity to impose local lockdowns), } \\
\text { resulting in food-price inflation, and if the supply system is difficult to } \\
\text { restart, then increase direct provision of food-especially in remote areas } \\
\text { with weakest links to national food chains. If rural areas experience a surge } \\
\text { in food demand due to returning urban populations who have lost work, } \\
\text { then local supply chains for food may come under intense pressure from a } \\
\text { demand spike, necessitating direct provision of food. } \\
\text { Food vouchers. School-feeding programmes (if schools are open). If closed } \\
\text { then find alternative ways to maintain child nutrition. Resumption of school } \\
\text { feeding is important once schools reopen as many children are likely to } \\
\text { return to school malnourished, the result of household income loss and } \\
\text { deterioration in access to health services. Food provision, including } \\
\text { nutritional supplements, linked to healthcare provision (e.g alongside polio } \\
\text { vaccination). } \\
\text { Include soap and other essential sanitary and health products with food } \\
\text { packages. } \\
\text { The implementation of CoviD-19 protective measures at food distribution } \\
\text { sites in humanitarian operations. } \\
\text { Utility waivers, or payments deferred, for electricity, water etc. Necessary to } \\
\text { maintain and increase household and community sanitary and washing } \\
\text { arrangements and cooking facilities. }\end{array}$ \\
\hline $\begin{array}{l}\text { Transition Phase out of } \\
\text { Pandemic }\end{array}$ & $\begin{array}{l}\text { Bundle ad hoc emergency programmes into more consolidated (and lower } \\
\text { admin cost) social protection. }\end{array}$ \\
\hline
\end{tabular}




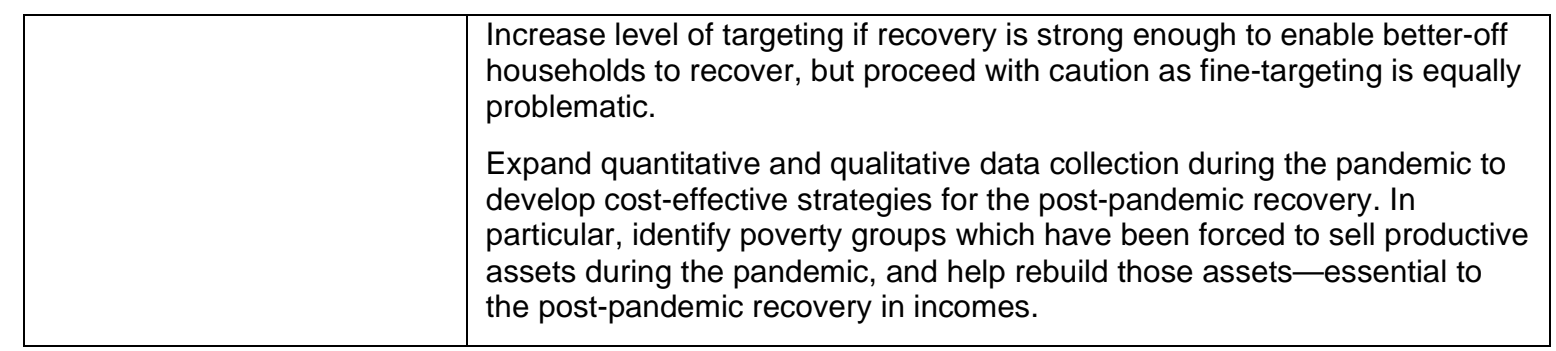

Note: this is by no means a fully inclusive list of all measures.

Source: authors' construction using Gentilini et al. (2020) and UNDP (2020a).

The most effective tools are those that prevent the separation of workers from the firms they work in (furloughing) and assistance to the self-employed via the tax system and bank loans (see Table 2). However, such fiscal policy tools are more difficult to enact in economies with large informal economies as the state cannot properly identify the wage-employed and self-employed through the tax system who would need such assistance, or reach out to them in a substantial manner. Cash transfer to the poor (or any other safety net measure) is an imperfect way to target this specific supply side problem. Alternatives include initiating large public works programmes in urban areas (but with caution as large gatherings of workers increase viral transmission) or to try and keep the sectors open where more of informal wage and self-employed are located (e.g construction, retail trade). This is a real challenge that Africa and South Asia are facing right now, and there is no easy 'one-size-fits-all' solution. Instead the balance must be struck at national, regional and indeed subregional levels (e.g. for cities and towns).

Nevertheless, the tension between lives and livelihoods is reduced to the degree that the government can find buyers for its debt, thereby allowing more public spending or tax cuts to support enterprises. Increasing the public debt is a means to transfer a portion of the burden of $H$-ESS to future generations who should be, once growth resumes, richer (and healthier) than today's citizens. ${ }^{61} \mathrm{~A}$ wage subsidy to firms to reduce firing takes a portion of the private-sector's wage bill onto the public accounts and, if debt-financed, transfers the burden forward to eventually be borne by future tax-payers. Advanced economies have much greater possibilities in this regard than LICs and MICs. They can currently issue debt with the longest possible maturities at nominal rates (and negative in real terms) only marginally above short-dated bonds. Allocating a portion of that borrowing to fund additional concessional finance and grant aid for the developing world would help poorer countries to transfer more of their burden forward, thereby easing the tension between lives and livelihoods.

\subsection{Mitigation versus suppression?}

Policy must deliver the components of the H-ESS package well, for they are mutually reinforcing. ${ }^{62}$ If $H$ proves inadequate, then repeated outbreaks will continue the need for ESS. But if ESS is weak then suppressing transmission by enforcing social distancing, including 'lockdowns', is infeasible as people on low-incomes must continue with their livelihood (if they can) and will be unable to maintain enough social distance or limit their movement sufficiently to stop transmission. The urban poor may move en masse to villages, seeking the informal safety net of

\footnotetext{
${ }^{61}$ Assuming that determined action is taken on climate change, otherwise the wealth and health of future generations will be much lower, as will the tax revenues available to service the long-term debt inherited from the current pandemic.

${ }^{62}$ Hale et al. (2020) provide a regularly updated tracker for government responses worldwide.
} 
the extended family and taking the virus with them. Then whatever health capacity is available risks being overwhelmed. ${ }^{63}$

Among, the LICs, Mozambique illustrates the constraints on households. Only 7 per cent of the population (and only 2 per cent in rural areas) live in conditions that allow for a strict lockdown: nearly all Mozambicans lack one or more of the resources needed to be fully ready, while only 29 per cent (and 14 per cent in rural areas) are partially ready (Jones et al. 2020). ${ }^{64}$ In Mozambique's cities and towns only 17 per cent of households are fully ready for a lockdown (and many people live in small dwellings in which it is infeasible to isolate the elderly and other high-risk people).

Transfers, preferably in cash, are vital (see Table 2). ${ }^{65}$ Transfers mitigate the income-shock from the economy's contraction; they reduce the scale of the contraction itself (by keeping consumption spending up); and they reduce illness and death from COVID-19 and the other diseases of poverty by supporting nutrition and the purchase of health services by households. ${ }^{66}$

Nevertheless, the ability of LIC households to survive lockdowns do not just depend on social protection and income support. Many people do not have the water and sanitation to survive a lockdown even temporarily. And without clean water and sanitation, confining people in close proximity risks outbreaks of communicable diseases like measles that are even more contagious than COVID-19. Refugees and internally displaced persons (IDPs) are very vulnerable. Crowded and insanitary camps in war zones force people into highly contagious environments. Unless they receive humanitarian assistance, they will not have the income or assets to maintain consumption.

If suppression is not feasible, and mitigation is pursued (slowing transmission by shielding the elderly and other vulnerable groups) then the health-service capacity of LICs and MICs could be overwhelmed. This is especially so if the number of sick achieves a high peak on the pandemic's first wave. Simulations by the Imperial College COVID-19 Response Team find that '.... our mitigated scenarios lead to peak demand for critical care beds in a typical low-income setting outstripping supply by a factor of 25 , in contrast to a typical high-income setting where this factor is $7{ }^{9}{ }^{67}$ These considerations were in the minds of India's government which announced a lockdown on 24 March at time when there were only 500 cases (in a population of 1.35 billion). If COVID-19 had been allowed to continue unabated, some 35 million individuals could have been hospitalized and 6 million deaths could have occurred in India. ${ }^{68}$

Africa's population age-profile may reduce the continent's vulnerability to the disease-and therefore pressure on its meagre health systems - as the elderly are at most risk, and only 4 per

\footnotetext{
${ }^{63}$ Many poor people make a livelihood from seasonal work as well, travelling far from their homes, sometimes crossing borders.

${ }^{64}$ Jones et al. (2020) use census data to calculate a lockdown readiness index for each household based on five indicators: access to electricity; access to clean drinking water; access to adequate sanitation; having a phone; and the household head is employed (so that food and other essentials can be purchased).

${ }^{65}$ On the importance of cash transfers see Dercon (2020) and Ravallion (2020b). Cash transfers are superior to direct food provision in most situations (see ODI-CGD 2015). More people can be assisted at no extra cost if cash is used instead of food (Margolies and Hoddinott 2014). On recommendations for Latin America, see Levy (2020).

${ }^{66}$ Intra-household impacts that must also be addressed, including the increased burden on women who undertake much of the health care in the family see Agarwal (2020); Borah et al. (2020); UNDP (2020b).

${ }^{67}$ Imperial College COVID-19 Response Team (2020: 1).

68 Sen (2020) using epidemiological modelling of COVID-19's global impact by the Imperial College COVID-19 Response Team (2020). On India's lockdown, also see Ray et al. (2020).
} 
cent of SSA's population is over 65 (in Europe the figure is around 20 per cent). ${ }^{69}$ However, Africa's high rates of malnutrition, untreated health conditions, and other communicable diseases exacerbate the health risk posed by the virus, and we do not yet know whether Africa's age-profile will work in its favour. Although the age-profile of a population may influence the balance between suppression and mitigation in a country's H-ESS strategy, especially in country's with very limited public finances, caution is needed as we do not yet have sufficient information on the virus's effects on the health of populations in low-income environments. ${ }^{70}$ Brazil, which now has one of the world's highest per capita death rates, remains a warning for those who glibly dismiss the lethality of the virus, while Vietnam offers a lesson in how to suppress transmission in a developing country.

In sum, the choice between suppression and mitigation is very much a function of a country's own resources, both financial and human - within both the state and community organizations-and the level of outside help it receives. International assistance during West Africa's Ebola crisis helped tilt the strategic balance towards suppression-mitigating the economic damage and the outbreak ended. International assistance will be much stretched given that COVID-19 is a world pandemic. But the more international assistance there is, the less is the intensity of the trade-offs facing policy makers. Given the greater borrowing power of the governments of advanced economies, it would be desirable to use some of it to fund increased concessional lending and aid grants for the developing world. We return to the financing issue later in the paper.

\subsection{Credibility}

Key decisions in public health include the scale of testing for suspected cases (including returnees, new arrivals in a country and whether they are quarantined and whether borders are sealed); how the ill are treated and in what facility; the timing of restrictions on mobility (early versus late); their severity (lockdowns versus curfews); their coverage (whether nationwide, or confined to areas with large outbreaks) and exceptions (for essential workers etc.). The timing of enterprise closures (and what constitutes an essential business) and income/consumption support to people losing jobs and businesses are at the centre of the strategy for economic and social support. Moreover, this is only the pandemic's first wave. A second wave, after lockdowns are relaxed, is expected, and the height of the peaks in cases and deaths of the successive waves is unpredictable. ${ }^{71}$ Dealing with successive waves raises its own set of decisions. Moreover, mass vaccination must be organized if (and when) a vaccine is available (perhaps by late 2021). ${ }^{72}$

Since success in managing the pandemic, entails managing expectations, communication is a vital area. This is a pandemic of the social media era, and these channels can transmit both accurate and inaccurate (and malicious) information. While mobile phone connectivity is now good across much of the developing world - allowing the use of texting for messages from the public health authorities-internet connectivity remains spotty (and the pandemic further demonstrates its value), and radio, TV as well as printed media remain important for communicating to citizens

\footnotetext{
${ }^{69}$ Bell (2020) compares Italy and Kenya, two countries with very different age-profiles and per capita incomes.

70 On how the age-profile of a population could influence the H-ESS strategy, see Basu and Sen (2020).

71 The second wave was the deadliest of the 1918-20 influenza pandemic.

${ }^{72}$ At least eight vaccines have gone to human trial: four in China, two in the US, and one each in Germany and the UK.
} 
about the pandemic itself as well as available H-ESS. It is vital to communicate effectively to the very poorest, and to indigenous people in remoter areas. ${ }^{73}$

However, it is now very late in the day. Some developing countries are making determined efforts to suppress the virus' transmission and the authorities have communicated clearly (Ghana and Vietnam are notable early-responders). At the same time, many have been slow or unable to establish the necessary $H$-ESS, with fragile states in the worst starting position, including violent conflict. Some national leaders are still in denial, resulting in either silence or confused messaging to citizens. This leaves citizens vulnerable to ill-informed or malicious messaging from sources other than the authorities.

Like conventional macroeconomic tools, the effectiveness of H-ESS depends on successfully managing expectations; thereby influencing private behaviour (monetary policy aims to reduces inflation expectations while $H$-ESS aims to increase social distancing, for example). For $H$-ESS to be successful, the authorities' actions must be credible in the eyes of citizens; they believe that the authorities will carry out the announced policy, and private behaviour will adjust accordingly (more people will socially distance after the authorities announce a rule). Delivery of the promised help is then essential, for failure reduces the credibility of future announcements (in the same way central banks have to follow through on announcements to build their credibility on inflation).

Citizens will be more likely to trust and follow policy announcements- thereby behaving in ways that policy success requires - in countries that built robust social contracts prior to the onset of the COVID-19 pandemic. Governments that effectively provided health care and social protection prior to COVID-19 (and successfully dealt with previous disease outbreaks such as Ebola, SARS$\mathrm{CoV}$, and Zika) begin the present crisis with a good stock of credibility, and can maintain it through consistent action that follows on from clear announcements.

Nevertheless, maintaining credibility in H-ESS is going to be far harder than in monetary policy. $H$-ESS has multiple targets (while monetary policy confines itself to price stability and, sometimes, employment). H-ESS has many more policy tools (which need to coordinate for overall success). We do not understand very well the link between H-ESS tools and its targets (because we do not fully understand the nature of SARS-CoV-2 itself). Behavioural responses to government actions are hard to predict (and will vary across cultures). Finally, behaviour in past epidemics is not necessarily a good guide.

Retaining policy credibility is harder as authorities will need to communicate necessary shifts in strategy as more information on the virus becomes available. They will inevitably make mistakes in early responses thereby creating uncertainty and fear among citizens, and they face the unexpected (e.g. food price shocks arising from COVID-19) and must react to events in neighbouring states which increase viral transmission across borders. A large measure of luck is needed, including the absence of natural disaster, which could derail pandemic responses by, for instance, large-scale population displacement.

\subsection{H-ESS and macroeconomic outcomes}

Since the present crisis began primarily as a health crisis, the loss of growth and investment, as well as any deterioration in the country's external position and debt profile, depend on the effectiveness of H-ESS measures. Consequently, $H$-ESS will matter as much as the conventional macro-policy instruments to the eventual macroeconomic impact of COVID-19. To give some

\footnotetext{
${ }^{73}$ See Ravallion (2020a) on the importance of effective communication.
} 
examples, if $H$-ESS reduces output and income losses by reducing death and illness then a greater debt/GDP ratio may be sustainable even as governments, faced with a revenue shock, borrow more to spend on essential services. Indeed, the dreadful logic is that reducing the death rate of productive workers reduces the pandemic's hit to tax revenues. And if H-ESS secures the viability of critical export and import-substituting sectors-by keeping workers healthy and wellnourished - then it can do as much, and probably more, to maintain foreign exchange reserves (and the value of the currency) as any complicated administrative scheme to ration foreign exchange among users.

$H$-ESS also affects macroeconomic outcomes by influencing the depth and duration of the pandemic and thereby households' propensity to save. Households are running down savings to maintain current consumption. If the pandemic is short lived, rebuilding households savings is feasible without much change in the long-run preference for savings. However, if the pandemic is long, with recurrent outbreaks and lockdowns, then uncertainty about livelihoods could result in a rise in the precautionary motive for savings, and a fall in the marginal consumption rate. This will alter some basic macroeconomic relationships (the national savings-investment gap, and thereby the current account deficit) and variables (including the economy's equilibrium rate of interest). ${ }^{74}$ This will in turn affect the pace of post-pandemic growth and job creation. ${ }^{75}$

Success in H-ESS will also affect the distributional characteristics of the eventual economic recovery: if the poor sell productive assets to maintain consumption (a common coping strategy), and if the middle-class fall into penury through job loss, then societies will emerge from the pandemic with even more inequality in their distributions of income and human development indicators. Large shifts in the ownership of assets have lasting effects on income-inequality over time, and on the pattern of economic growth (both its sectoral composition-more inequality will change the composition of sectoral demand—as well as its inclusivity). ${ }^{76}$

In sum, the tools with the most potency in determining the 'final' macroeconomic outcomes from COVID-19 are not fiscal and monetary policy—as important as they are-but the H-ESS package. Thus, the conventional macroeconomic tools of fiscal and monetary policy play a vital, though secondary role, while H-ESS aggressively attacks the virus, and its impact on public health and the economy. To adopt a military metaphor, the conventional macroeconomic tools provide logistical support to the H-ESS front-line. All of this makes the COVID-19 crisis very different from crises originating in the financial system such as the 2008-09 GFC (and the 1998 Asian Financial Crisis).

\section{The scope for macroeconomic policy responses in developing countries}

COVID-19 constitutes both a supply shock and a demand shock. The aggregate supply of final goods and services falls as production shrinks due to illness, social distancing and restrictions on movement, and the disruption of supply chains for inputs. When expectations of business profitability decline, investors hold back new investment. Aggregate demand falls, as domestic income falls, and eventually consumption falls_-after households deplete their savings sell assets. Falling export demand compounds the production, income, and consumption declines. For small

\footnotetext{
${ }^{74}$ Goy and van End (2020).

75 Perhaps reinforcing the trend to secular stagnation evident in the advanced economies prior to COVID-19.

76 South Africa is just one example. Even in normal times, about 70 per cent of South Africans who experience downward mobility enter a situation of structural poverty - having lost assets - from which it is very hard to escape Schotte 2020).
} 
and highly open economies, the external demand shock is greater than for large economies with lower trade-to-GDP shares. The commodity price crash is one transmission mechanism from the international economy, a fall in remittance income is another (e.g., in countries like Bangladesh that supply labour to the Gulf region) and, depending on monetary responses in the advanced economies, any tightening of global credit markets reduces the availability and cost of corporate and sovereign borrowing.

Expansionary fiscal and monetary policy can mitigate the scale of the aggregate supply and demand contraction and its impact on overall economic growth and employment. However, it cannot entirely offset it. Among the developing countries, the large emerging market economies (China, India etc.) can manoeuvre the most. Large domestic markets provide some scope for fiscal and monetary stimulus to offset the aggregate demand effect of external demand shocks. They have large domestic financial markets (with an appetite for the government debt required to finance bigger fiscal deficits). Moreover, their foreign currency debt (both sovereign and corporate) remains attractive to international investors, given that US and other investment-grade debt has exceptionally low yields (which are now falling further as the Fed, the ECB, the Bank of Japan and the Bank of England pursue aggressive monetary easing).

That said, emerging market economies, which remain over-dependent on primary commodity exports, are feeling the most heat (notably in Latin America). Those which built fiscal buffers to deal with commodity price downturns, will fare better (e.g., Chile). Those that entered the COVID19 crisis with already high debt/GDP rations, large current account deficits (and dependence on foreign debt financing), and already weak currencies have less room for fiscal and monetary manoeuvre. Turkey is vulnerable in this way. Debt downgrades have begun: in March, Moody cut South Africa's debt rating to junk, after 25 years at investment grade. Argentina defaulted in May, after missing an interest payment on its dollar debt. Nevertheless, for emerging economies as a group, the international capital markets continue to lend (though in smaller amounts) and the picture is not as gloomy as it was in March before the Fed and other major central banks pushed unprecedented liquidity into the markets.

The LICs as well as the LMICs (many of them recent LIC 'graduates') are under the most stress. They have small manufacturing sectors mostly serving domestic markets (with a few exceptions such as Bangladesh and Ethiopia which have significant export manufacturing), and depend on commodity exports, tourism, and remittances for their foreign exchange earnings. For the oil importers among them, the oil price collapse provides a sizeable saving on the import bill. Yet, this will almost certainly be offset, on average, by the loss of export earnings due to weaker export prices, cancelled orders, and disrupted supply chains. ${ }^{77}$ So, on average, the likely outcome is a negative terms-of-trade shock for most LICs and many MICs (at least for the present, the outlook then depends on how fast China, and the world economy, recovers and with it the demand for commodities).

LICs and LMICs with oil and gas and mining face a big fall in their revenues and foreign exchange reserves. The current price of US $\$ 38$ a barrel (for Brent oil) is far below the break-even price of the budgets of the world's oil producers (Nigeria assumed a price of US $\$ 57$ in planning its 2020

\footnotetext{
77 Bangladesh, the world's second largest clothing exporter after China, has seen the cancellation of some US $\$ 2.6$ billion of orders, according to the industry association (https://www.bgmea.com.bd). Africa's producers of fresh fruit, vegetables and flowers face logistical disruptions in air and sea transport to European and Asian markets.
} 
budget, and Brent has been as low as USD $\$ 21) \cdot{ }^{78}$ Many have not built large fiscal buffers (nor sizeable foreign exchange reserves) to cover cyclical downturns in prices, let alone a shock of the COVID-19 magnitude. Within SSA, the oil producers have seen the largest jump in spreads on their sovereign bonds. ${ }^{79}$ The yield on Angola's dollar Eurobonds went above 20 per cent in March, well into distressed debt-territory (and its debt now tops 100 per cent of GDP); issuing enough debt to cover its yawning fiscal deficit appears infeasible.

Many African countries enter the crisis with already high debt-ratios, much of it is on nonconcessional terms, and debt-service already accounts for large percentages of tax revenues and export-earnings. Zambia is highly vulnerable in this way (debt-service took one-third of government revenues in 2019, and takes maybe one-half today). ${ }^{80}$ Zambia's debt is now at distressed levels, as is Mozambique's.

Portfolio outflows from emerging markets over March 2020 were about US $\$ 100$ billion (US $\$ 83$ billion in March, alone), five times larger than during a comparable period of the GFC. ${ }^{81}$ The Fed's liquidity measures provided temporary respite for debtors over April-May, by maintaining some appetite to purchase risky debt. Yields on African debt have fallen though they remain elevated. Nevertheless, debtors are very likely to need debt relief in the coming months. We discuss this below.

Borrowing dollars at a time when the dollar is appreciating (a traditional safe haven in times of crisis) adds further risk, not least when the borrowers' export prices are weak. Currencies are now under pressure across the LICs and MICs. The unappetising policy choice is between defending a pre-crisis official exchange rate (and accept a depletion in reserves) or to accept depreciation (resulting in higher import prices and higher debt service in dollar terms).

Capital controls may help to shore up the official exchange rate for a while, and conserve foreign exchange. The currency will still depreciate in unofficial markets, and central banks will watch for any widening gap between the official and parallel rate, which is a sign of accelerating capital flight. Nevertheless, even with capital controls_-and when reserves are low-defending the currency is time-bound and when the market recognizes this it accelerates selling. This results in an over-shoot in the exchange rate adjustment when the central bank eventually capitulates (thereby increasing the size of the import price shock beyond the level of an earlier controlled devaluation, and passing the shock through to domestic food prices, the prices of key imported inputs and to the medical supplies bill).

If the macroeconomic crisis is so severe that policy makers lose credibility, then bond yields will spike (adding to fiscal pressures) and commercial foreign financing may dry up completely. Countries, which cannot obtain sufficient external finance, may return to foreign exchange rationing-prevalent in the macroeconomic crises of the 1980s-aiming to prioritise essential

\footnotetext{
${ }^{78}$ The fiscal 'break-even' price is the minimum price that the government of an oil producer needs to meet its spending commitments while balancing its budget (i.e. oil prices below this level will result in a fiscal deficit, unless government policies change).

${ }^{79} \mathrm{IMF}(2020 \mathrm{c} ; \mathrm{v})$.

${ }^{80} \operatorname{IMF}(2019: 11)$.

81 See IIF 'Capital Flows Tracker: The COVID-19 Cliff, 20 April: https://www.iif.com/Portals/0/Files/content/1_IIF_Capital\%20Flows\%20Tracker_April.pdf. These are portfolio outflows by non-residents. See also the speech by IMF Managing Director, Kristalina Georgieva, 9 April: https://www.imf.org/en/News/Articles/2020/04/07/sp040920-SMs2020-Curtain-Raiser.
} 
imports. Such rationing has its own problems, being prone to abuse, but may be a last resort in the absence of generous external financial support.

Currency swaps between central banks help central banks maintain domestic financial stability (crucial to maintaining borrowing and investment by the private sector). Indirectly, they provide some currency support by boosting domestic confidence (thereby reducing capital flight). Currency swaps between the central banks of advanced economies are longstanding and in March, the Fed and five other central banks coordinated their expansion to ensure market liquidity. ${ }^{82}$ The US authorities are keen to avoid further dollar appreciation.

The US authorities include some emerging economies (e.g. Brazil and Mexico) in swap arrangements and could extend this to others (e.g. South Africa). However, the Fed generally only extends dollar swap lines to economies with strong fundamentals. This excludes the LICs. ${ }^{83}$

Generous balance of payments assistance from multilateral and bilateral donors is imperative to ease adjustment and maintain confidence in currencies. ${ }^{84}$ More than 100 countries have requested IMF assistance. The IMF board had approved support of US $\$ 50$ billion for emerging economies and US $\$ 10$ billion for LICs, including via its Rapid Credit Facility by the end of April. ${ }^{85}$ The IMF is replenishing its Catastrophe Containment and Relief Trust (CCRT), which provides rapid debt service relief on IMF debt obligations; it was down to only US $\$ 150$ million pre-pandemic, and US $\$ 1.4$ billion is the new target (it now has US $\$ 500$ million after new pledges, and 25 LICs are eligible). ${ }^{86}$ The CCRT needs large cash balances upfront to commit to full debt service relief, and it may exhaust its resources before every eligible country's needs are met unless the Fund's target for replenishment (US\$1.4 billion) is met. $^{87}$

An expansion of members' special drawing rights (SDRs), which will boost their reserves, is imperative. Yet, it remains politically blocked. SDRs were last increased, by US $\$ 297$ billion, in 2009 during the GFC ${ }^{88}$ Policy makers discussed further increases in subsequent years, and perhaps the pandemic will finally break the logjam, though the 2020 Spring Meetings were another missed opportunity. The case against-and this is the longstanding position of the United States, the largest IMF shareholder-is that the G20 countries would receive 70 per cent of the allocation (since they have the largest quotas). In the US view, they do not need them (while the share of the

\footnotetext{
${ }^{82}$ Board of Governors of the Federal Reserve System 'Coordinated Central Bank Action to Enhance the Provision of US Liquidity' Press Release (15 March):

https://www.federalreserve.gov/newsevents/pressreleases/monetary20200315c.htm.

83 Some African central banks have swap arrangements with China (e.g. Nigeria).

84 On financing responses see IMF (2020d) and Morris (2020).

85 https://www.imf.org/en/About/Factsheets/Sheets/2016/08/02/21/08/Rapid-Credit-Facility. On the Rapid Credit Facility and other IMF facilities see IMF (2020d).

86 On 13 April, the IMF announced immediate debt relief for 25 members after the CCRT qualification criteria were expanded to better cover the circumstances of the pandemic:

https:/ /www.imf.org/en/News/Articles/2020/03/27/pr20116-imf-enhances-debt-relief-trust-to-enable-supportfor-eligible-lic-in-wake-of-covid-19. The CCRT was established in response to the 2010 Haiti earthquake, and also provided debt relief for Guinea, Liberia, and Sierra Leone in 2015 in response to the Ebola outbreak.

${ }^{87}$ Pre-funding the CCRT has proven hard, given the many other demands on scarce donor grant funding, including their own bilateral aid programmes (IMF 2020e: 6).

${ }^{88}$ IMF (2018).
} 
LICs in any SDR increase could be as low as 3 per cent). ${ }^{89}$ However, a US $\$ 1$ trillion increase in SDRs - with the number under discussion - would represent a large absolute rise in LIC resources (and many MICs, including G20 members such as South Africa, could make good use of extra SDRs in defending their currencies). ${ }^{90}$ Moreover, G7 and some G20 countries could transfer a portion of their increased SDR allocation to needy LICs and LMICs, a proposal previously made for the financing of international action on TB and HIV/AIDs. ${ }^{11}$ While the technical case for an SDR increase remains robust, US opposition makes it unlikely to happen this year.

With sovereign debt markets under strain, development banks can borrow on more favourable terms than is possible for small LICs (which may be unable to attract lenders at all). In March 2020, the African Development Bank (AfDB) successfully placed a US $\$ 3$ billion 'Fight COVID19 Social Bond', which was oversubscribed. ${ }^{92}$ However, a post mortem will be necessary for the World Bank's pandemic bonds: the Bank only announced the payouts on April 19, after the final criterion was met (an exponential growth rate in virus infections in (IDA) countries eligible for payouts). This is hardly the early surge in financing pandemic-bonds were supposed to achieve. Moreover, the amount (US $\$ 132.5$ Million) is tiny compared to the US $\$ 160$ billion in finance, which the World Bank is providing to its clients from other sources over the next 15 months. ${ }^{93}$

Overall, these measures are a good start. However, the world community needs more-especially on SDRs. Debt relief is especially urgent. African Ministers of Finance have called for US $\$ 44$ billion of debt relief as part of an additional funding package of US $\$ 100$ billion. ${ }^{94}$ In April, senior African economists called for a two-year standstill on all external debt payments, both principal and interest, including commercial as well as official debt. ${ }^{95}$ The World Bank has called for a standstill on official bilateral debt-service payments, and at the IMF/World Bank 2020 spring meetings, the $G 7$ countries backed a (time-bound) suspension of debt service payments on official bilateral claims, if joined by the G20 and as agreed with the Paris Club.

Early clarification of the G20 countries position on official debt relief is vital. China's position, as the largest G20 lender to the LICs and LMICs and the world's largest official creditor (though not a Paris club member), will be central in determining the trajectory of official debt relief in this crisis. ${ }^{96}$ Official creditors are a more diverse group than in the last major round of official debt relief, which ended over a decade ago. ${ }^{97}$ Considerable G7-G20 cooperation will be required, but

\footnotetext{
${ }^{89}$ Sobel (2020) expresses scepticism and Gallagher et al. (2020) respond to the sceptics. Fundamentally, the issue is geopolitical rather than technical: the US is opposed to an increase in SDRs as this would also benefit China and Iran. India is also apparently wary of an SDR increase, for reasons that are unclear at present.

90 Gordon Brown and Larry Summers have proposed a US\$1 trillion increase in SDRs (Brown and Summers 2020).

${ }^{91}$ See Soros (2002). UNCTAD (2020a: 10) also makes the case for a reallocation of SDRs towards the developing countries. The debate on SDR increases is a long-running one: see Aryeetey (2004: 90-109.).

${ }^{92}$ Central banks and official institutions accounted for 53 per cent of the buyers of AfDB's 'Fight COVID-19 Social Bond'.

${ }^{93}$ For critical analysis of pandemic bonds, drawing on evidence from the West Africa Ebola outbreak of 2014-16, see Brim and Wenham (2019).

94 'African Ministers of Finance: Immediate call for US $\$ 100$ billion support and agreement the crisis is deep and recovery will take much longer’. UNECA Communiqué, 31 March 2020: https://www.uneca.org/stories/communiqu\%C3\%A9-african-ministers-finance-immediate-call-100-billion-

support-and-agreement-crisis.

95 Okonojo-Iweala et al. (2020).

${ }^{96}$ On China as a creditor (and the difficulties of measuring the scale of China's lending), see Horn et al. (2020).

${ }_{97}$ On the Heavily-Indebted Poor Countries (HIPC) Initiative, see Addison et al. (2004). On the Enhanced-HIPC and MDRI, see Addison (2006).
} 
the US-China trade dispute, as well current US-China tension over the pandemic itself, does not bode well. ${ }^{98}$ Appeals for the next G20 meeting to be brought forward from November have come to nought.

While a start has been made on official debt relief via the standstill announced at the Spring meetings, this still leaves private sector debt, which has become an increasing share of the total debt outstanding (and therefore debt service) of LICs and LMICs over the last decade or so. ${ }^{99}$ The IMF and official institutions are encouraging private creditors to join in debt standstills. Until they do so, the standstill on official debt simply leads to a reallocation of payments on official debt to repay private creditors out of diminishing foreign-exchange earnings, and does not increase the debtor's capacity to import essential medical and food supplies. ${ }^{100}$

If private creditors volunteer to defer payment (which the $\mathrm{G} 7$ is encouraging them to do) then the credit-ratings agencies could declare the countries to be in default, and will downgrade the debt accordingly (and this will certainly occur if debtors take unilateral action). ${ }^{101}$ In addition, independently of what the credit-rating agencies do, private-sector perceptions of risk are now very high. The risk of a credit freeze and contagion spreading right across the class of emergingmarket debt (and thence into the international financial system) remains high, notwithstanding the unprecedented liquidity injection by the major central banks. It would be better for both debtors and creditors-and for containing the spread of the virus itself-if the G7-G20 takes decisive action in the arena of private debt. This will preserve the ability of debtors to maintain and increase their public spending during the pandemic and to use their foreign exchange to purchase vital imports rather than make interest payments. A similar consideration applies to any increase in SDR allocations.

Workouts of private debt are notoriously difficult to arrange given the range of creditors, and they are typically slow. There is every incentive for some creditors to hold out to get better terms (and to pursue litigation in order to seize the foreign assets of debtors if they unilaterally declare debt moratoriums). ${ }^{102}$ The result is a prolonged depression among the debtors last seen in the debt crises of the 1980s when external commercial financing dried up. The MICs will be the main debtors affected, as they have the largest proportion of private debt. However, the LICs face more serious trouble than in past crises, given the growth of commercial lending to them in recent years.

\section{$5 \quad$ Final observations and conclusions}

Induced by the pandemic, economies are now undergoing major structural adjustments. Some sectors expand, while others contract, even while GDP slows, flattens, or falls. Some of this will

\footnotetext{
98 On international cooperation see Obstfeld and Posen (2020).

99 The HIPC Initiative and the MDRI led to a positive re-rating of the LICs and LMICs and low yields on the highly rated debt of advanced economies after the GFC encouraged private investors to 'reach for yield' by turning to LIC and LMIC debt. The commodity super-cycle of 2003-14 encouraged debt accumulation, as export-earnings were buoyant. The range of private-sector creditors has expanded as a result (in the 1980s debt crises it was mainly banks, now a wide range of institutional investors hold considerable amounts of LIC and LMIC sovereign bonds). Coulibaly et al. (2019) discuss the pre-pandemic growth in Africa's commercial debt.

100 Bolton et al. (2020) propose the creation of a central credit facility for each country, overseen by the World Bank or another multilateral institution, whereby countries could deposit stayed interest payments for use in emerging financing during the pandemic.

101 Moody's (2020: 2) has already signalled this.

102 Herman et al. (2010).
} 
reverse after the 'all clear' sounds - the return of the retail and leisure-economies, for example. Other structural changes will remain after COVID-19 becomes a memory. Lives lost before their time constitute permanent losses of human (and social) capital. Some physical capital could lose considerable value (aircraft and airport infrastructure in particular). Supply chains may become more local than global after the pandemic, changing the nature of globalization in a post-pandemic world.

Health services expand during pandemics together with the manufacture and distribution of medicines and equipment. Capital and labour need to shift accordingly. The response to COVID19 is akin to wartime mobilization with resource allocation determined more by the state and less by markets (in extremis, directed labour and conscription loom). Which businesses survive, and which fail, will be determined more by the state and less by credit markets (which contract as risks rise). Opportunities for rent-seeking abound, and public subsidies and bail-outs need to be transparent and in the public interest.

Policy can be potent. It can also amount to 'pushing on a piece of string' when behaviour alters in ways that cannot easily be influenced by the authorities (as monetary policy in times of deflation illustrates). As with financial crises, a narrative develops around pandemics, and the Keynesian 'animal spirits' that drive private investment decisions; fearful people are reluctant to invest or consume, thereby deepening recession and slowing eventual recovery. This is very much a crisis of the social media age, and false information is easily distributed. It will take time for expectations to 'normalize' by anchoring themselves, and meanwhile high uncertainty will affect the pace and nature of structural adjustments - in particular reinvestment back into high-risk activities.

A long pandemic, with repeated outbreaks, will generate the largest structural changes (international tourism will wither, for instance). Activities requiring movement between homes and non-essential workplaces are vulnerable if they cannot shift into the digital economy. The digital economy increases a society's resilience to pandemics, it will expand further, and it as essential to the LICs as it is to the richer countries. However, the digital economy cannot plant maize, harvest rice, sell soap in a village market, stitch clothing for export, or dig out mineralsall activities central to LIC economies and livelihoods. Moreover, e-government is rudimentary in most LICs (and many MICs) and will need to expand.

More goods and services will be produced within the home economy and therefore outside of the market economy during the pandemic, and maybe afterwards as lower household incomes leave less money for restaurants, cleaning services, and nurseries. This might encourage a proper valuation of unpaid homework in national account statistics. In the meantime, the time-burden falls on women who are the main providers of these services in the home, together with family healthcare. This is likely to reduce female participation in education and in the labour market, lowering their lifetime earnings, and increasing gender income-inequality.

The pandemic's distributional impact (in terms of income and wealth and other metrics) could be profound, depending on what direction policy takes. The key question is whether policy will leave the poor to cope as best they can. Or, will policy put more encompassing social protection and healthcare in place? The private and social returns to the skills of survivors will alter. Distributional shifts will in turn feedback into the economy's structure, depending on whether wealth and incomes become more or less concentrated-resulting in changing patterns of consumption and employment.

The labour market will be at the centre of distributional change. More people will fall back on the informal economy as formal businesses shut down. Many of those still working in the formal sector could end up on flexible contracts, with little job protection-especially when working from 
home through the digital economy or via piecework. Women with rising time-burdens in the home, and less education and skills, will be vulnerable. Capital will push for labour market flexibility via deregulation. At the same time, 'reshoring' of manufacture back to the advanced economiesalready a trend with automation which reduces the importance of labour costs and increases the profit share of value added-will favour workers in the advanced economies at the expense of labour-intensive export-manufacturing in the developing world.

Distributional struggle will also be evident in the public finances. Politics as much as economics will determine who pays, and in what ways. With indirect taxes falling as market-activity stalls, there will be more demand to tax online retail, thereby setting up a struggle to extract revenue from powerful multinational companies. Faced with a collapse in oil prices, oil economies must mobilize revenue from indirect and direct taxes, thereby changing the relationship between rentier and autocratic governments and their citizens.

Although the world avoided the 2008-09 GFC turning into a repeat of the 1930s Great Depression, rising inequality within countries has marked the recovery over the last decade, and it is not evident, as some claim, that the pandemic will reconfigure politics and policy in ways that make society fairer. Indeed, some of the political response to the pandemic reflects the legacy of the GFC, which saw a growth in populism feeding on inequality, a disregard for international obligations, and a willingness to 'beggar-thy-neighbour'. A post-pandemic recovery could easily include a trend of rising inequality and could indeed accelerate it yet further.

Relationships between nation states, and whether cooperation prevails, will also determine outcomes. Whereas the GFC saw considerable international policy co-ordination across central banks and within the $\mathrm{G} 7$, the pandemic occurs at a time of weak international cooperation and outright economic conflict - manifest in the 'trade war' between the US and China — and the undermining of international organizations such as the WTO, and now the WHO, by the US administration. With so much manufacturing in the advanced economies in distress, there will be calls for protectionism against imported goods, especially from China. Whether international cooperation recovers, or weakens further, will affect the distribution of COVID-19's human and economic costs across nations including the severity and duration of each country's recession. In addition, a slide into protectionism would make a repeat of the Great Depression of the 1930s more likely.

LICs and LMICs will bear heavy costs, both human and economic, if the advanced economies reserve essential medical supplies for their own citizens (and a vaccine once one is developed), and if they cut, rather than expand, ODA and other concessional financial support. Moreover, if they do so, the virus will continue to spread in the developing world, and then back into the developed world. International cooperation protects national interests better than unilateral action. However, the temptations of nationalism are now evident among hard-pressed political leaders.

There is much more to say about the economic impact of COVID-19. We have only touched on some of the distributional and poverty effects, and we have not discussed state fragility. Instead, we have confined our attention to some of the principal macroeconomic dimensions of the pandemic.

As bad as COVID-19 is, it is not the very worst global health disaster imaginable; a rapid spread of new antibiotic resistant microbes may eventually take that 'honour'. Moreover, there may be a vaccine and one in sufficient quantities, by the end of 2021 (the current best guess, though optimism seems to be falling). In the meantime, while many will recover from the virus (and immunity may develop), many will die before their time, families will be bereaved, and we will see all of the social ills associated with lost jobs, lost education, and heightened anxiety. 
While economists regularly focus on such aggregates as GDP losses-with policy aiming to minimize the economic damage-it is vital to keep in mind that even as economies eventually recover, there will be an immense legacy of harm to human happiness. Those costs can last far into the future-and it must be the job of economic policy to help contain the damage from COVID-19 and minimize its legacy of harm, while building a recovery that does not reinforce already deep social inequalities.

\section{References}

Addison, T. (2006). 'Debt Relief: The Development and Poverty Impact', Swedish Economic Policy Review, 13: $205-30$.

Addison, T., C. Arndt, and F. Tarp. (2011). 'The Triple Crisis and the Global Aid Architecture'. African Development Review, 23(4): 461-78. https:// doi.org/10.1111/j.1467-8268.2011.00299.x

Addison, T., H. Hansen, and F. Tarp (eds) (2004). Debt Relief for Poor Countries. Basingstoke: Palgrave Macmillan for UNU-WIDER. https://doi.org/10.1057/9780230522329

Agarwal, B. (2020). 'COVID-19 and Lockdowns: are women more affected?', WIDER Blog. https://www.wider.unu.edu/publication/covid-19-and-lockdowns

Alon, T.M., M. Doepke, J. Olmstead-Rumsey, M. Tertilt. (2020). 'The Impact of COVID-19 on Gender Equality'. NBER Working Paper, 26947. Cambridge MA: National Bureau of Economic Research. https://doi.org/10.3386/w26947

Arndt, C., R. Davies, S. Gabriel, L. Harris, K. Makrelov, B. Modise, S. Robinson, W. Simbanegavi, D. van Seventer, and L. Anderson (2020). 'Impact of Covid-19 on the South African economy - An initial analysis'. SA-TIED Working Paper, 111. Helsinki: UNU-WIDER.

Aryeetey, E. (2004). 'A Development-Focused Allocation of the Special Drawing Rights'. In T. Atkinson (ed.) New Sources of Development Finance. Oxford: Oxford University Press for UNU-WIDER. https://doi.org/10.1093/0199278555.003.0005

Baldwin, R. (2020). 'The Supply Side Matters: Guns Versus Butter, COVID-style'. VoxEU.org, 22 March. https://voxeu.org/article/supply-side-matters-guns-versus-butter-covid-style

Basu, P. and K. Sen (2020). 'Age Composition of Population and Covid-19'. WIDER Blog (https://www.wider.unu.edu/publication/age-composition-population-and-covid-19) and Ideas4India https://www.ideasforindia.in/topics/macroeconomics/age-composition-of-populationand-covid-19.html

Bell, C. (2020). 'COVID-19: Mortality, Future Years Lost, and Demographic Structure; Italy and Kenya Compared'. WIDER Working Paper, 2020/60. Helsinki: UNU-WIDER. https://doi.org/10.35188/UNU-WIDER/2020/817-7

Bellemare, M. (2014). 'Rising Food Prices, Food Price Volatility, and Social Unrest'. American Journal of Agricultural Economics, 97(1): 1-21). https://doi.org/10.1093/ajae/aau038

Bernanke, B. (2004). Essays on the Great Depression. Princeton: Princeton University Press.

Blanchard, O. (2020). 'High Inflation is Unlikely but not Impossible in Advanced Economies'. PIIE Blog, 24 April. https://www.piie.com/blogs/realtime-economic-issues-watch/high-inflation-unlikely-notimpossible-advanced-economies

BOFIT (2020). 'China Posts Larger-Than-Expected Budget Deficit for 2019'. BOFIT Weekly 2020/10, 6 March. Helsinki: Bank of Finland Institute for Economies in Transition.

https://www.bofit.fi/en/monitoring/weekly/2020/vw202010_3/

Bolton, P., L. Buchheit, P-O. Gourinchas, M. Gulati, C.-T. Hsieh, U. Panizza, B. Weder di Mauro (2020). Necessity is the Mother of Invention: How to implement a comprehensive debt standstill for 
COVID-19 in low- and middle-income countries'. VoxEU.org, 21 April.

https://voxeu.org/article/debt-standstill-covid-19-low-and-middle-income-countries

Borah, A., S. Das, A. Dasgupta, A. Deshpande, K. Mahajan, B. Ramaswami, A. Saha, A. Sharma (2020). 'The Coronavirus Pandemic; Are we ready for the long haul?'. Policy Brief, 1. Ashoka University: Centre for Economic Analysis and Data (CEDA) https://www.ashoka.edu.in/page/CEDA-369

Brim, B., and C. Wenham (2019). 'Pandemic Emergency Financing Facility; struggling to deliver on its innovative promise'. British Medical Journal, 367. https://doi.org/10.1136/bmj.15719

Brown, G.. and L. Summers (2020). 'Debt Relief Is the Most Effective Pandemic Aid'. Project Syndicate, 15 April. https://prosyn.org/R4LyrUJ

Calderon, C., G. Kambou C.Z. Djiofack, M. Kubota, V. Korman, and C.C Canales (2020). 'Assessing the Economic Impact of COVID-19 and Policy Responses in Sub-Saharan Africa'. Africa Pulse, 21 (April). Washington DC: World Bank. https://doi.org/10.1596/978-1-4648-1568-3

Cerra, V., and S.C. Saxena (2017). 'Booms, Crises, and Recoveries: A New Paradigm of the Business Cycle and its Policy Implications'. IMF Working Paper, 17/250. Washington DC: International Monetary Fund. https://doi.org/10.5089/9781484325759.001

Chang, R., and A. Velasco (2020). 'The Virus Turns South'. Project Syndicate (24 March). https://www.project-syndicate.org/commentary/policy-response-to-covid19-in-latin-america-byroberto-chang-1-and-andres-velasco-2020-03

Chen, M. (2020). 'To Die from Hunger or the Virus: an all too real dilemma for the poor in India (and elsewhere)'. WIDER Blog. https://www.wider.unu.edu/publication/die-hunger-or-virus

Coulibaly, B.S., D. Ghandhi, and L.W. Senbet (2019). 'Is Sub-Saharan Africa Facing Another Systemic Sovereign Debt Crisis?' Africa Growth Initiative Policy Brief. Washington DC: Brookings Institution.

Dercon, S. (2020). 'As Outcomes Are Uncertain, Pick No-Regret Policies'. CGD Blog, 17 April. Washington DC: Centre for Global Development. https://www.cgdev.org/blog/as-outcomes-areuncertain-pick-no-regret-policies\#.Xp

Doepke, M. and M. Tertilt (2016). 'Families in Macroeconomics'. In J. Taylor and H. Uhlig (eds) Handbook of Macroeconomics, vol. 2. Amsterdam: North Holland. https:// doi.org/10.1016/bs.hesmac.2016.04.006

Espitia, A., N. Rocha, and M. Ruta (2020). 'COVID-19 and Food Protectionism: The Impact of the Pandemic and Export Restrictions on World Food Markets'. Policy Research Working Paper, 9253. Washington DC: World Bank.

EUI-GTA-WB (2020). 'COVID-19 Trade Policy Database: Food and Medical Products'. Brief, 4 May. European University-Global Trade Alert-World Bank. https://www.worldbank.org/en/topic/trade/brief/coronavirus-covid-19-trade-policy-databasefood-and-medical-products.print

Evenett, S. (2020). 'On Tariffs, Soap and Tackling COVID-19'. Trade For Development News Blog,18 March. https://trade4devnews.enhancedif.org/en/op-ed/tariffs-soap-and-tackling-covid-19

FAO (2020). 'Global Food Commodity Prices Drop Further in April'. 7 May. Rome: Food and Agricultural Organization of the UN. http://www.fao.org/news/story/en/item/1273914/icode/

Gallagher, K.P., J.A. Ocampo, and U. Volz (2020). 'IMF Special Drawing Rights: A key tool for attacking a COVID-19 financial fallout in developing countries', Future Development Blog, 26 March. Washington DC: Brookings. https://www.brookings.edu/blog/futuredevelopment/2020/03/26/imf-special-drawing-rights-a-key-tool-for-attacking-a-covid-19-financialfallout-in-developing-countries/

Gentilini, U., M. Almenfi, I. Orton, and P. Dale (2020). 'Social Protection and Jobs Responses to COVID19: A Real-Time Review of Country Measures'. COVID-10 Living Paper, 1 May. Washington DC: World Bank Group. http://documents.worldbank.org/curated/en/883501588611600156/Social- 
Protection-and-Jobs-Responses-to-COVID-19-A-Real-Time-Review-of-Country-Measures-May-12020

GNFC (2020). Global Report on Food Crises 2020. Rome: World Food Programme for the Global Network Against Food Crises and Food Security Information Network (FSIN).

Gourinchas, P-O. (2020). 'Flattening the Pandemic and Recession Curves'. In R. Baldwin and B. Weder di Mauro (eds), Mitigating the COVID Economic Crisis: Act Fast and Do Whatever It Takes. London: CEPR Press.

Goy, G. and J.W. van End (2020). 'The Impact of the COVID-19 crisis on the Equilibrium Interest Rate'. VoxEU.org, 20 April. https://voxeu.org/article/impact-covid-19-crisis-equilibrium-interest-rate

Hale, T., A. Petherick, T. Phillips, and S. Webster (2020). 'Variation in Government Responses to COVID-19’, Blavatnik School of Government Working Paper, 2020/031 (Version 4.01). www.bsg.ox.ac.uk/covidtracker

Herman, B., J.A. Ocampo, and S. Spiegel (eds) (2010). Overcoming Developing Country Debt Crises. Oxford: Oxford University Press for the Initiative for Policy Dialogue at Columbia University. https://doi.org/10.1093/acprof:oso/9780199578788.001.0001

Hevia, C. and A. Neumayer (2020). 'A Conceptual Framework for Analyzing the Economic Impact of the COVID-19 and its Policy Implications', COVID-19: Policy Document Series 1. New York: UNDP Latin America and the Caribbean

Holland, D., and I. Liadze (2020). 'Quantifying the Global Macroeconomic Spillovers of Illness and Lockdown'. National Institute Economic Review, 252 (May): 69-70.

Horn, S., C.M. Reinhart, and C. Trebesch (2020). 'How Much Money Does the World Owe China?'. Harvard Business Review, 26 February. https://hbr.org/2020/02/how-much-money-does-the-worldowe-china

IMF (2018). 'Considerations on the Role of the SDR'. Policy Paper. Washington DC: International Monetary Fund.

IMF (2019). '2019 Article IV Consultation — Press Release; Staff Report; and Statement by the Executive Director for Zambia'. IMF Country Report, 19/264. Washington DC: International Monetary Fund.

IMF (2020a). World Economic Outlook. 2020; Chapter 1 The Great Lockdown. Washington DC: International Monetary Fund.

IMF (2020b). Fiscal Monitor; Chapter 1 - Policies to Support People During the COVID-19 Pandemic. Washington DC: International Monetary Fund.

IMF (2020c). Regional Economic Outlook: Sub-Saharan Africa - COVID-19: An Unprecedented Threat to Development. Washington DC: International Monetary Fund

IMF (2020d). 'Enhancing the Emergency Financing Toolkit—Responding To The COVID-19 Pandemic'. Policy Paper, 020/18. Washington DC: International Monetary Fund.

IMF (2020e). 'Catastrophe Containment and Relief Trust; Policy Proposals and Funding Strategy'. Policy Paper, 020/17. Washington DC: International Monetary Fund.

Imperial College COVID-19 Response Team (2020). 'The Global Impact of COVID-19 and Strategies for Mitigation and Suppression'. London: WHO Collaborating Centre for Infectious Disease Modelling, MRC Centre for Global Infectious Disease Analysis, Abdul Latif Jameel Institute for Disease and Emergency Analytics and Imperial College London. https://doi.org/10.25561/77735

Jones, S., E-M. Egger, and R. Santos (2020). 'Is Mozambique prepared for a lockdown during the COVID-19 pandemic?'. WIDER Blog. https://www.wider.unu.edu/publication/mozambiqueprepared-lockdown-during-covid-19-pandemic

Keynes, J.M. (1936). The General Theory of Employment, Interest and Money. London: Macmillan.

Kindleberger, C.P. (1973). The World in Depression, 1929-1939. Berkeley: University of California Press. 
Laborde, D., W. Martin and R. Vos (2020). Poverty and Food insecurity could Grow Dramatically as COVID-19 Spreads'. IFPRI Blog: Research Post, 16 April. Washington DC: International Food Policy Research Institute. https://www.ifpri.org/blog/poverty-and-food-insecurity-could-growdramatically-covid-19-spreads

Levy, S. (2020). 'Suggestions for the Emergency'. COVID-19: Policy Document Series 2. New York: UNDP Latin America and the Caribbean

Margolies, M., and J. Hoddinott (2014). 'Costing Alternative Transfer Modalities, Journal of Development Effectiveness. 7(1). https:// doi.org/10.1080/19439342.2014.984745

Martin, W., and K. Anderson (2011). 'Export Restrictions and Price Insulation during Commodity Price Booms'. Policy Research Working Paper, 5645, Washington DC: World Bank. https:// doi.org/10.1596/1813-9450-5645

Moody's (2020). 'Debt Relief Will Benefit Low-Income Countries, But Raises Prospect of Defaults on Private-Sector Debt'. 15 April. New York: Moody's Investor Service. https://www.moodys.com/researchdocumentcontentpage.aspx?docid=PBC_1222307

Morris, S. (2020). 'Coronavirus Response: Addressing the Near-Term Financing Needs of Low-Income Countries'. CGD Blog, 18 March. Washington DC: Centre for Global Development. https://www.cgdev.org/blog/coronavirus-response-addressing-near-term-financing-needs-lowincome-countries

Obstfeld, M., and A. Posen (eds) (2020). How the G20 Can Hasten Recovery from COVID-19. Washington DC: Peterson Institute for International Economics.

Gallagher, K., J.A. Ocampo and U. Volz (2020). 'IMF Special Drawing Rights: A key tool for attacking a COVID-19 financial fallout in developing countries'. In UN-CDP (ed.) Development Policy and Multilateralism after COVID-19. New York: United Nations:.

ODI-CGD (2015). 'Doing Cash Differently; How cash transfers can transform humanitarian aid - report of the High Level Panel on humanitarian cash transfers', London: Overseas Development Institute and the Center for Global Development.

Okonojo-Iweala, N., B. Sangafowa Coulibaly, T. Thiam, D. Kaberuka, V. Songwe, S. Masiyiwa, L. Mushikiwabo, and C. Duarte (2020). 'Africa Needs Debt Relief to Fight COVID-19'. Op-Ed, 9 April. Washington DC: Brookings Institution. https://www.brookings.edu/opinions/africa-needsdebt-relief-to-fight-covid-19

Pinstrup-Andersen, P. (ed.) (2014). Food Price Policy in an Era of Market Instability; A Political Economy Analysis. Oxford University Press for UNU-WIDER. https://doi.org/10.1093/acprof:oso/9780198718574.001.0001

Posen, A. (2020). 'Containing the Economic Nationalist Virus through Global Coordination'. In R. Baldwin and B. Weder di Mauro (eds), Mitigating the COVID Economic Crisis: Act Fast and Do Whatever It Takes. London: CEPR Press: 203-211.

Raga, S. and D.W, te Velde (2020). 'Economic Vulnerability to Health Pandemics; Which Countries are Most Vulnerable to the Impact of the Coronavirus'. London: Overseas Development Institute, Supporting Economic Transformation (SET) Programme.

Ravallion, M. (2020a). 'On the Virus and Poor People in the World'. Economicsandpoverty.com Post, 2 April. https://economicsandpoverty.com/2020/04/

Ravallion, M. (2020b). 'Could Pandemic Lead to Famine?' Project Syndicate, 15 April. https://www.projectsyndicate.org/commentary/covid19-lockdowns-threaten-famine-in-poor-countries-by-martinravallion-2020-04

Ray, D., S. Subramanian, and L. Vandewalle (2020). 'India's Lockdown'. Policy Insight, 102. London: Centre for Economic Policy Research. https://cepr.org/sites/default/files/policy_insights/PolicyInsight102.pdf 
Schotte, S. (2020). 'Temporary Shock or Lasting Poverty Trap? COVID-19 in South Africa'. Blog. https://www.wider.unu.edu/publication/temporary-shock-or-lasting-poverty-trap

Sen, K. (2020). 'COVID-19 and socioeconomic impact in Asia: The case of India', WIDER Background Note, 2020/01. Helsinki: UNU-WIDER. https://doi.org/10.35188/UNU-WIDER/WBN/2020-1

Shiller, R. (2017). 'Narrative Economics', NBER Working Paper, 23075. Cambridge MA: National Bureau of Economic Research. https://doi.org/10.3386/w23075

Sobel, M (2020). 'Coronavirus SDR allocation nto the answer'. OMFIF Nens \& commentary, 24 March. Singapore: Official Monetary and Financial Institutions Forum (OMFIF). https://www.omfif.org/2020/03/coronavirus-sdr-allocation-not-the-answer/

Soros, G. (2002) 'Special Drawing Rights for the Provision of Public Goods on a Global Scale'. Washington DC: Peterson Institute for International Economics.

Sumner, A., C. Hoy, and E. Ortiz-Juarez (2020). 'Estimates of the Impact of COVID-19 on Global Poverty'. WIDER Working Paper, 2020/43. Helsinki: UNU-WIDER. https://doi.org/10.35188/UNU-WIDER/2020/800-9

Tadesse, G., B. Algieri, M. Kalkuhl, and J. von Braun (2014). 'Drivers and Triggers of International Food Price Spikes and Volatility', Food Policy, 47: 117-28. https://doi.org/10.1016/j.foodpol.2013.08.014

UNCTAD (2020a). "The Covid-19 Shock to Developing Countries; Towards a "whatever it takes" programme for the two-thirds of the world's population being left behind'. Geneva: United Nations Conference on Trade and Development.

UNCTAD (2020b). 'Impact of COVID-19 Pandemic on Global FDI and GVCs'. Investment Trends Monitor (March). Geneva: United Nations Conference on Trade and Development.

UNDP (2020a). Covid-19 and Human Development; Assessing the Crisis, Envisioning the Recovery. New York: United Nations Development Programme.

UNDP (2020b). 'The Economic Impacts of COVID-19 and Gender Inequality; Recommendations for policy-making'. Briefing Note. New York: United Nations Development Programme, Latin America and the Caribbean.

UN-ECA (2020). 'African Ministers of Finance: Immediate call for $\$ 100$ billion support and agreement the crisis is deep and recovery will take much longer'. UN-ECA Communiqué, 31 March. Addis Ababa: United Nations Economic Commission for Africa. https://www.uneca.org/stories/communiqu \%C3\%A9-african-ministers-finance-immediate-call100-billion-support-and-agreement-crisis

WFP (2020a). Yemen Country Brief, April 2020. Rome: World Food Programme.

WFP (2020b). Syria Country Brief, April 2020. Rome: World Food Programme.

WHO (2020a). 2019 Novel Coronavirus (2019-nCoV): Strategic Preparedness and Response Plan. Geneva: World Health Organization (3 February).

WHO (2020b). COVID-19 Strategy Update. Geneva: World Health Organization.

WHO (2020c). Strengthening and Adjusting Public Health Measures throughout the COVID-19 Transition Phases: Policy Considerations for the European Region. Geneva: World Health Organization.

WHO (2020d). Considerations in Adjusting Public Health and Social Measures in the Context of COVID-19: Interim Guidance. Geneva: World Health Organization.

Wong, C. (2011). 'The Fiscal Stimulus Programme and Public Governance Issues in China'. OECD Journal on Budgeting 11(3). https:/ / doi.org/10.1787/budget-11-5kg3nhljqrjl

World Bank (2020a) East Asia and Pacific in the Time of COVID-19. Washington DC:

World Bank (2020b). 'World Bank Predicts Sharpest Decline of Remittances in Recent History'. Press Release, 2020/175/SPJ. https://www.worldbank.org/en/news/press-release/2020/04/22/worldbank-predicts-sharpest-decline-of-remittances-in-recent-history 
WTO (2020). 'Trade Set to Plunge as COVID-19 Pandemic Upends Global Economy'. Press Release, 855, 8 April. Geneva: World Trade Organization.

https://www.wto.org/english/news_e/pres20_e/pr855_e.htm 